\title{
3
}

\section{O QUADRO INSTITUCIONAL DA REESTRUTURAÇÃO DA DÍVIDA EXTERNA NO ÂMBITO INTERNACIONAL}

À parte de regras materiais que forneçam soluções consistentes à inexecução da dívida pública, tampouco há processos uniformes destinados a reestruturar a dívida pública. Conforme o credor da dívida pública, diversas instituições atuam em bases eventuais, nomeadamente as organizações internacionais de caráter intergovernamental com vocação econômica, entre as quais se destacam as funções exercidas pelo FMI. Outros entes não tradicionais, tais como os Clubes de Paris e de Londres, são locais de encontros entre credores e Estados devedores de importância fundamental para o entendimento do modo de funcionamento atual das reestruturações da dívida pública, que são, como este capítulo pretende mostrar, definidas a partir de um enquadramento institucional mínimo.

Esta cambiante distribuição de competências, que redistribui as importâncias relativas dos atores envolvidos conforme a natureza de cada crise e as espécies de credores envolvidos, observou importante evolução diante de consideráveis desafios econômicos. A ação organizada de entidades internacionais oferece uma casuística relevante, sem que se possa perder de vista de que este é um trabalho ainda em curso, e que o quadro jurídico-institucional da dívida pública em âmbito internacional tem desenvolvimento desigual em comparação com outros campos de atuação de instituições financeiras internacionais criadas pelos acordos de Bretton Woods. Trata-se de um conjunto de regras relativamente subdesenvolvido, cuja análise atenta já o chamou de "rudimentar", ${ }^{256}$ e cuja incapacidade de atender satis-

256 "The international rules governing the handling of default and of borrowers in difficulty be they sovereign or corporate are at best rudimentary (...). This is an area of international law 
fatoriamente às necessidades de desenvolvimento o colocou "abaixo da marca do razoável." ${ }^{257}$ Os grandes debates globais sobre o regime jurídico da resolução de crises da dívida pública no pós-segunda guerra se iniciaram tardiamente, na década dos 70, com uma preocupação específica: a ineficiência dos mecanismos até então existentes para conter o comportamento oportunista de credores individuais, pelo que se buscavam instrumentos funcionais de estabilização dos conflitos entre as suas diversas classes e o Estado devedor. A primeira e principal fragilidade dos procedimentos negociados de redefinição dos pagamentos da dívida pública seria identificada, então, com os insuficientes incentivos para que se chegasse ao acordo pretendido e que esta proposta acolhesse a agenda econômica dos países em desenvolvimento.

Não é de surpreender, portanto, que preocupação de complementar o cenário financeiro internacional com instituiçōes direcionadas a articular soluções para a descontinuidade efetiva ou potencial dos serviços da dívida pública externa se tenham primeiro relacionado ao período do Diálogo Norte-Sul. Esta etapa da diplomacia econômica se refere ao envolvimento de países em desenvolvimento da Ásia, da África e da América Latina, muitos dos quais recém-independentes, em negociações sobre as mudanças do sistema econômico internacional com países industrializados da América do Norte e da Europa Ocidental. Antes das crises generalizadas da dívida pública na década seguinte, os países identificados com o Sul convergiram para incorporar na nova realidade econômica o tema do alívio do endividamento como medida capaz de absorver o impacto dos desequilíbrios generalizados nas balanças de pagamentos dos países em desenvolvimento,

which has been neglected since the 1930's. The world's financial system has in effect raced ahead of the institutional infrastructure for crisis management." (SURATGAR, D. The International Financial System and the Management of the International Debt Crisis. In: BRADLOW, D. International Borrowing: Renegotiating and Structuring International Debt Transactions. Washington, D.C.: Springer, 1986, p. 677).

257 "While the search for strategies acceptable both to debtors and creditors has been intense and has evolved considerably in the past decade, the results achieved are far from satisfactory. It is true that the breakdown of the international financial system has been avoided by the international community. However, from the point of view of the major debtor states and from the perspective of an equitable allocation of global welfare, the process and its effects have fallen below the mark of reasonableness. The impacts of the debt situation on the rate of growth in the countries concerned, the effects on the social fabric, and the consequences for the state of the environment will not allow a different conclusion." (DOLZER, R. Ten Years of Multi-Annual International Debt Management. Cairo Conference (1992) Committee on International Monetary Law. Londres: International Law Association, 1992, p. 18). 
provocados em grande parte pela deterioração dos termos de troca e pela crise do petróleo. ${ }^{258}$ Em conjunto com a questão dos elevados encargos da dívida econômica em uma conjuntura internacional desafiadora, o tema institucional de uma maquinaria permanente que substituísse os clubes de Paris e de Londres para a reestruturação das dívidas bilateral e bancária, respectivamente, se apresentou como uma preocupação relevante em torno do prenunciado espectro das moratórias generalizadas dos países em desenvolvimento. ${ }^{259}$

Se, durante o Diálogo Norte-Sul, a preocupação com o alívio da dívida externa como forma de cooperação havia impulsionado a discussão de uma nova institucionalidade internacional do endividamento público, a discussão ganharia um enfoque complementar na década que viria a seguir. Os níveis insustentáveis dos empréstimos bancários aos países em desenvolvimento inseririam a discussão sobre a responsabilidade das fontes de capitais pelo endividamento dos países em desenvolvimento. As considerações sobre a os níveis excessivos de empréstimos tomados não poderiam ignorar o reverso da moeda, o excesso de empréstimos concedidos sem a devida diligência da parte dos bancos comerciais credores. $\mathrm{O}$ problema do overborrowing era complementado, assim, com a percepção dos problemas do overlending. ${ }^{260}$ Se tanto credores quanto devedores tinham sido parte no ciclo de entusiasmo de empréstimos internacionais abundantes e baratos, os custos das eventuais crises financeiras deveriam encontrar formas de distribuição equitativa entre o Estado tomador e o fornecedor do crédito. $\mathrm{O}$ resgate financeiro de bancos comerciais por organismos multilaterais com o FMI e o Banco Mundial acrescentaria novos incentivos para o excesso de liquidez internacional, o que implicava o risco de percepção subjetiva, ou moral hazard, de que a existência de um emprestador de último caso distorcesse a percepção do risco nos empréstimos bancários. Estratégias diferentes, que equilibrassem os custos para todas as partes, poderiam conduzir os mercados financeiros internacionais, tanto do lado dos devedores como dos

${ }^{258}$ RIEFFEL, L. Restructuring Sovereign Debt: the Case for Ad Hoc Machinery. Washington, D.C.: Brookings Institution Press, 2003, p. 1606; AMUZEGAR, J. The North-South Dialogue: From Conflict to Compromise. Foreign Affairs, Washington, D.C., vol. 54, n. 3, abr. 1976.

259 OECHSLI, C. Procedural Guidelines for Renegotiating LDC Debts: An Analogy to Chapter 11 of the US Bankruptcy Reform Act. Virginia Journal of International Law, Charlottesville, vol. 21, n. 2, 1981, p. 305-341.

260 STIGLITZ, J. Making Globalization Work: the Next Steps to Global Justice. Londres: Penguin Books, 2006, p. 216-218. Sobre aspectos mais gerais, ver LINDERT, P.; MORTON, P. How Sovereign Debt has Worked. In: SACHS, J. Developing Country Debt and Economic Performance. Chicago: University of Chicago Press, 1989, vol. 1, p. 39-106. 
credores, a adotar comportamentos mais prudentes do que aqueles até então observados, reduzindo-se a pressão para contrair empréstimos. ${ }^{261}$

Todas estas considerações acabaram por ter alguma consequência para os mecanismos de resolução das crises de endividamento, os quais operam a partir de negociações entre o Estado e seus diversos credores. $\mathrm{O}$ tratamento institucional desse tema tem recebido, como visto, atenção importante principalmente nos últimos trinta anos, a partir da preocupação de identificar situações ineficientes dos atuais mecanismos de reestruturação da dívida pública. $\mathrm{O}$ modo de ação específica de diversas instituições envolvidas evidencia tanto as regras mais estáveis, fixadas, por exemplo, pelo costume internacional, e outras em estado de transformação devido à revisão das estratégias adotadas.

\subsection{RENEGOCIAÇÕES}

Fundamental no complexo normativo das renegociações da dívida pública é a própria exigibilidade jurídica das renegociações, ou a obrigação de renegociar. A revisão dos acordos financeiros do Estado, quer se dê a reestruturação por reescalonamento, por redução ou por recompra, implica algum risco para a confiabilidade do Estado. Neste sentido, as ações unilaterais são geralmente evitadas em favor da preservação de sua reputação financeira. Determinados estudos sobre as condições de existência da dívida pública apontam a potencialidade da exclusão dos mercados financeiros como o principal fator que conduz ao pagamento da dívida pública, o que explica a continuidade do funcionamento do mercado de crédito ao Estado. A questão faz sentido porque, de um lado, os bens públicos localizados no exterior não são suficientemente numerosos para assegurar a satisfação de todos os seus credores em caso de execução por um tribunal estrangeiro, e, de outro, as garantias concedidas sobre os bens localizados em seu próprio território seriam insuficientes para inspirar suficiente credibilidade pois dependeriam, em última instância, da vontade do Estado para cumpri-las.

O risco do crédito pode não ser o único relevante para a dívida contratual com outros Estados e organizações multilaterais que, para conceder empréstimos, obedecem a critérios que não são puramente econômicos. A transferência voluntária de capitais privados ao Estado, no entanto, o toma em conta como elemento de primeira linha. As condições de existência de um mercado para a dívida pública

261 Para a análise do problema específico do "risco moral" (moral hazard) em empréstimos bancários para Estados, ver LIENAU, O. Rethinking Sovereign Debt: Politics, Reputation, and Legitimacy in Modern Finance. Cambridge: Harvard University Press, 2014, p. 233. 
levam à formulação da hipótese de que, na ausência de instrumentos que permitam aos credores ter controle sobre o patrimônio do Estado, a única possível sanção ao inadimplemento da dívida pública é a exclusão dos mercados de capitais, isto é, a interrupção dos fluxos de financiamento a partir de um dado momento. ${ }^{262} \mathrm{Se}$ o Estado não conta com recursos próprios suficientes para se proteger de choques de produtividade e para isso depende do financiamento pela poupança privada, a ameaça de exclusão destes canais de empréstimos seria motivo suficiente para que se preocupasse em pagar a dívida, até determinados níveis. Estes níveis são tanto mais altos quanto maior for a variação da produtividade e quanto mais dependa o Estado dos mercados internacionais de capitais para responder às variações da sua produção.

Ainda que haja evidências de que a exclusão dos mercados financeiros seja temporária e que nem sempre o histórico de defaults implica o encarecimento permanente dos empréstimos a determinado Estado, ${ }^{263}$ uma política deliberada de não cumprimento dos contratos teria impacto sobre as relações econômicas com o exterior, tanto com o setor público como privado. $\mathrm{O}$ risco de crédito é um fator sensível à avaliação de agências de risco e a própria elegibilidade a organizações intergovernamentais poderia ser comprometida. ${ }^{264}$ A consensualidade em torno das conversōes é, portanto, uma situação preferível aos interesses do Estado.

A renegociação não é, portanto, um evento desfavorável às partes se consideradas as alternativas do inadimplemento puro e simples ou das reestruturações forçadas. Por meio dela, o devedor pode receber a assistência financeira necessária, e os credores têm a oportunidade de reavaliar as condições econômicas correntes e o potencial para a retomada de investimentos no país. ${ }^{265} \mathrm{Alguns}$ aspectos gerais das

${ }^{262}$ Esta é a tese desenvolvida pelo artigo seminal de J. Eaton e M. Gersovitz. Cf. Debt with Potential Repudiation: Theoretical and Empirical Analysis. Review of Economic Studies, Oxford, vol. 48, n. 2, 1981, p. 289-309. A propósito, ver também TOMZ, M. Reputation and International Cooperation: Sovereign Debt Across Three Centuries. Princeton: Princeton University Press, 2007.

263 EICHENGREEN, B.; PORTES, R. Dealing with Debt: The 1930s and the 1980s. In: HUSAIN, I.; DIWAN, I. Dealing with the Debt Crisis. Washington, D.C.: The World Bank, 1989, p. 69-86; LINDERT, P.; MORTON, P. How Sovereign Debt has Worked. In: SACHS, J. Developing Country Debt and Economic Performance. Chicago: University of Chicago Press, 1989, vol. 1, p. 40.

${ }^{264}$ MEETHARBAN, M. Vers un Droit International de la Dette Extérieure? In: CARREAU, D.; SHAW, M. (Coord.). La Dette Extérieure. Haia: Martinus Nijhoff Publishers, 1995, p. 508.

265 OECHSLI, C. Procedural Guidelines for Renegotiating LDC Debts: An Analogy to Chapter 11 of the US Bankruptcy Reform Act. Virginia Journal of International Law, Charlottesville, vol. 21, n. 2, 1981, p. 305-341 
etapas de negociação anteriores às reestruturações podem ser aqui destacados. A partir da declaração de interesse em reestruturar a sua dívida pública, a qual pode preceder ou suceder à suspensão parcial ou total dos pagamentos, o acordo entre credores e devedores em conversões não forçadas conduzirá ao desenvolvimento de etapas de negociação entre todas as partes. Em linhas gerais, o objetivo do acordo de reestruturação é a definição dos termos de novação das obrigações financeiras, de forma a atingir alguma redução nos encargos do serviço da dívida e, com o alívio, proceder aos pagamentos sem solução de continuidade ou, caso os pagamentos já tenham sido descontinuados, retomar o fluxo dos reembolsos aos credores. $\mathrm{Ou}-$ tro importante objetivo das negociações é divulgar informaçôes relevantes sobre o estado das contas públicas, bem como as estratégias fiscais e de gerenciamento da dívida. ${ }^{266}$

Do ponto de vista dos governos, é necessário que se tomem algumas medidas para a preparação de um acordo de reestruturação. A primeira delas é o conhecimento do volume total da dívida pública, com a adequada diferenciação dos tipos de instrumentos financeiros envolvidos, tanto em seus aspectos jurídicos como financeiros. O conjunto destas características é complexo, o que demonstra que os processos de reestruturação envolvem um conjunto de informações muito diversificado. As obrigações se diferenciam quanto ao cronograma de amortização, os juros previstos podem ser fixos ou variáveis, pagos em parcelas ou apenas ao final do prazo de maturidade, as moedas de denominação são distintas, há obrigações garantidas, o valor de face deve ser comparado com o valor de mercado dos títulos e, enfim, cláusulas específicas de cada contrato determinam uma ou outra forma de vinculação dos credores às ofertas de troca. ${ }^{267} \mathrm{~A}$ análise destes fatores permite definir o perfil da dívida pública e calcular a dimensão do esforço necessário para o ajuste macroeconômico e do alivio dos encargos do endividamento calculado pelas partes. ${ }^{268}$ Desta forma serão orientadas as ofertas de troca a serem apresenta-

266 DAS, U.; PAPAIOANNOU, M.; TREBESCH, C. Sovereign Debt Restructurings 19502010: Literature Survey, Data, and Stylized Facts. Washington, D.C.: FMI, 2012, p. 12.

267 Estas são os elementos-chave apontados por LIM, R.; MEDEIROS, C.; XIAO, Y. Quantitative Assessments of Sovereign Bond Restructurings. Material não publicado, 2005.

${ }^{268}$ Há vários critérios para o dimensionamento das reduções esperadas, mas as principais consideram a diferença existente entre os valores atuais dos novos títulos lançados (somados a eventuais pagamentos em espécie) em relação ao valor de face das obrigaçôes antigas. Para as fórmulas mais frequentes, ver, principalmente, STURZENEGGER, J.; ZETTELMEYER, B. Creditor Losses versus Debt Relief: Results from a Decade of Sovereign Debt Crises. Journal of the European Economic Association, vol. 5, n. 2/3, abr.-maio 2007, p. 343-51. 
das aos credores, o que exige tempos variáveis de preparação. Assim que concluída a proposta, a oferta é apresentada aos credores para que a aceitem ou rejeitem, tendo participado de sua elaboração em maior ou menor extensão. O sucesso desta etapa depende de um número mínimo de adesões, que deverão ser manifestadas entre a apresentação da proposta e a reestruturação final. Neste período, portanto, os problemas de coordenação tendem a ser maiores. A conclusão desta fase permitirá saber, então, o percentual de credores participantes e também o tamanho das reduçôes no valor de mercado dos títulos em relação ao valor de face, chegando-se ao tamanho dos cortes que os credores enfrentarão nos pagamentos da dívida pública.

No plano jurídico, a apresentação de uma proposta de negociação pode ser prevista nos próprios contratos, que contêm dispositivos sobre eventos de default e os requisitos de modificação das cláusulas contratuais. É possível sustentar o dever jurídico de renegociar as obrigaçôes, no entanto, não apenas em cláusulas contratuais válidas para cada obrigação, mas em fundamentos mais amplos, relacionados à ideia de transição do direito internacional de um direito de coexistência para um direito de cooperação. ${ }^{269}$ Colocada em termos do direito ao desenvolvimento, a cooperação internacional em matéria de dívida pública encontra parâmetros programáticos introduzidos como norma positiva nos artigos 55 e 56 da Carta da ONU, em que os objetivos econômicos e sociais de estabilidade e bem-estar são colocados em vinculação com açôes cooperativas desenvolvidas junto às Nações Unidas. ${ }^{270}$ Como pedra de toque da nova ordem econômica internacional colocada no diálogo entre países do hemisfério norte e sul, o tratamento potencial das relações econômicas e financeiras internacionais foi consolidado nos princípios da Carta de Direitos Econômicos das Naçôes Unidas, de 1974, que postula a cooperação como fator essencial dos objetivos de desenvolvimento. ${ }^{271}$ Outros fundamentos

269 Cf. FRIEDMANN, W. The Changing Structure of International Law. Nova Iorque: Columbia University Press, 1964.

${ }^{270}$ Carta das Naçóes Unidas, ONU, 1945. Art. 55: “[w] ith a view to the creation of conditions of stability and well-being which are necessary for peaceful and friendly relations among nations based on respect for the principle of equal rights and self-determination of peoples, the United Nations shall promote: a. higher standards of living, full employment, and conditions of economic and social progress and development; b. solutions of international economic, social, health, and related problems; and international cultural and educational cooperation; and c. universal respect for, and observance of, human rights and fundamental freedoms for all without distinction as to race, sex, language, or religion." E, no art. 56, “[a]1l Members pledge themselves to take joint and separate action in co-operation with the Organization for the achievement of the purposes set forth in Article 55."

271 Charter of Economic Rights and Duties of States, ONU, 1974. 
possíveis foram encontrados na obrigação de perseguir a solução pacífica das controvérsias internacionais ${ }^{272} \mathrm{e}$, em relação mais imediata com o tema das condições de vida das populações de menor renda, no caráter erga omnes dos direitos humanos. ${ }^{273}$

Em sentido mais concreto, o dever de cooperação em matéria de renegociação da dívida pública é apontado como uma obrigação de meio, e não de resultado, em que se busca uma proposta comum face a interesses divergentes, levadas a termo com boa-fé. O tratamento jurídico do dever internacional de negociar é mais bem estabelecido em outros campos temáticos, como a definição de fronteiras marítimas, os quais, no entanto, contêm princípios relevantes para os conflitos entre Estados. A obrigação de negociar para chegar a um acordo foi objeto do Caso da Plataforma Continental do Mar do Norte, em que se entendeu que o diálogo entre as partes deve ser guiado pelo interesse real de que as negociaçôes cheguem a um acordo, e que não devem consistir apenas de um processo formal. ${ }^{274}$ Este dever de entabular negociaçóes entre os Estados fez com que o frequente acesso ao clube de Paris para a reestruturação da dívida bilateral pudesse ser definido como uma norma costumeira, e os costumes parecem aqui desempenhar aqui um importante papel. O fato de que os Estados adotem a prática constante e generalizada de reestruturar a dívida pública de forma negociada teria criado uma norma internacional cogente. Como bem aponta Reinisch, "o dever geral de cooperação junto com um dever amplamente compreendido de prestar assistência aos países em desenvolvimento pode criar o dever positivo de renegociar as obrigações internacionais da dívida”. ${ }^{275}$

Mas uma norma de tal natureza no direito internacional é matéria de significativa controvérsia. Isto porque, a despeito da prática frequente, faltaria a convicção da juridicidade da parte dos Estados de que estão obrigados a renegociar com os credores. Assim, já se argumentou que o recurso a entidades organizadoras das

272 KÄMMERER, J. Der Staatsbankrott aus völkerrechtlicher Sicht. Zeitschrift für ausländisches öffentliches Recht und Völkerrecht, Heidelberg, vol. 65, s. n., 2005, p. 651-676.

273 BOTHE, M.; BRINK, J. Public Debt Restructuring: the Case for International Economic Cooperation. German Yearbook of International Law, Berlim, vol. 29, 1986, p. 86-100.

274 CIJ, North Sea Continental Shelf Cases, 1969, p. 47-48.

275 Debt Restructuring and State Responsibility. In: CARREAU, D.; SHAW, M. (Coord.). La Dette Extérieure. Haia: Martinus Nijhoff Publishers, 1995, p. 549, tradução livre. No original, "[i]t rather seems that the general duty to co-operate together with a broadly understood duty to give assistance to LDCs [less developed countries] might entail a positive duty to renegotiate international debt obligations." 
renegociações da dívida pública evidenciaria a necessidade da intervenção de instâncias multilaterais que formalizassem as propostas oficiais, e isto, ao contrário de indicar a existência de um direito costumeiro, provaria exatamente o contrário: que a falta de convicção sobre o dever de recorrer a soluções consensuais levaria as partes a se precaverem por meio de um ato documentado juridicamente vinculante. ${ }^{276}$ Neste sentido se toma como apoio a decisão do Caso Socobel (1939), no qual se afirmou que as dificuldades do governo grego para pagar as obrigações devidas a uma empresa belga não poderiam significar que qualquer das partes ou o Estado belga estivessem obrigados a chegar a um acordo amigável. ${ }^{277}$ Negava-se, então, que o país credor ou algum de seus nacionais tivessem o dever de negociar em razão das dificuldades de pagamento do devedor.

Com relação à dívida bilateral, no entanto, pode-se apontar que, desde a década de 1980, as reestruturaçôes têm ocorrido com tanta frequência nos moldes do Clube de Paris, de forma negociada, que haveria um costume internacional in statu nascendi. ${ }^{278}$ A desarticulação dos elementos jurídicos da questão fica mais evidente quando se muda a análise para o crédito privado, em que as bases de afirmação de uma obrigação de renegociar em âmbito internacional são mais tênues. $O$ princípio da boa-fé, por exemplo, exigiria um compromisso com soluções cooperadas. Outra sustentação a este dever seria, como se encontra em alguma literatura sobre o tema, a analogia ao direito falimentar interno dos Estados, a partir do qual se tentaria derivar alguma obrigação internacional. O raciocínio é o de que, da mesma maneira que as partes não podem ser furar a procedimentos falimentares no âmbito interno que as colocassem em contato com o devedor insolvente para articular soluçôes à sua recuperação ou à liquidação de seus bens, não faria sentido que nenhuma forma de mecanismos semelhantes operasse no contexto externo ao Estado. ${ }^{279}$ Os procedimentos de reestruturação da dívida comercial ou mobiliária

276 LEYENDECKER, L. Auslandsverschuldung und Völkerrecht. Berna: Peter Lang, 1988, p. 286.

277 CPJI, The "Société Commerciale de Belgique", série AB, n. 78, 1939, p. 21, em que se lê: "[a]part from any other consideration, it is certain that the Court is not entitled to oblige the Belgian Government-and still less the Company which is not before it-to enter into negotiations with the Greek Government with a view to a friendly arrangement regarding the execution of the arbitral awards which that Government recognizes to be binding: negotiations of this kind depend entirely upon the will of the parties concerned."

${ }^{278}$ REINISCH, A. Debt Restructuring and State Responsibility. In: CARREAU, D.; SHAW, M. (Coord.). La Dette Extérieure. Haia: Martinus Nijhoff Publishers, 1995, p. 549.

${ }^{279}$ GOLDMANN, M. Responsible Sovereign Lending and Borrowing: the View from Domestic Jurisdictions. Nova Iorque: UNCTAD, 2012. 
apenas se legitimariam, portanto, caso obedecessem a alguma disciplina ordenada, semelhante a um procedimento de insolvência. ${ }^{280}$

O argumento analógico estranha, no entanto, por ser aplicável apenas de lege ferenda e, ainda que se procurasse observar alguma ordenação com base em princípios similares aos do direito falimentar interno, seria preciso definir qual é o Estado de referência. $\mathrm{O}$ desenvolvimento de mecanismos institucionais análogos aos do direito falimentar é um tema complexo que tem recebido maior atenção nos últimos anos. Este é justamente um dos cenários institucionais propostos mais recentemente para aperfeiçoar os mecanismos internacionais de resolução das crises da dívida pública, o que mostra que a analogia é admissível, mas não automaticamente derivável do estado de coisas atualmente existente.

As atuais instâncias mobilizadoras das renegociações da dívida pública atuam seguindo procedimentos próprios. Este modo de agir é um aspecto particularmente sensível a uma dada categorização da dívida pública. Conforme o tipo de credor envolvido, há procedimentos específicos que direcionarão as negociações que ocorrem entre o oferecimento de uma proposta e a conclusão do acordo. Estes procedimentos se distinguem quanto à dívida oficial bilateral e à dívida com credores privados, sejam consórcios bancários ou portadores de títulos públicos. Estas instâncias traçam, por sua vez, uma distinção primordial a respeito de qual dívida deve ser reestruturada, o que pressupõe que nem todas as categorias da dívida pública são tratadas da mesma forma. As categorias reestruturáveis da dívida definem qual parte das obrigaçōes financeiras será reestruturada, mas também aquelas que não serão. A dívida multilateral é particularmente distinta de outros tipos neste sentido, pois as organizações financeiras multilaterais não costumam se submeter às mesmas dificuldades para seus reembolsos, que são, salvo algumas exceções, excluídos de processos de reestruturação.

Os processos transcorridos em entidades vocacionadas à reestruturação da dívida bilateral ou perante consórcios bancários, respectivamente os Clubes de Paris e de Londres, serão apresentados posteriormente, dado que se trata de um ambiente institucional mais organizado a despeito das características informais dessas entidades. A natureza das reduções de endividamento mediante renegociações da dívida mobiliária será tratada na última parte, dadas as peculiaridades de programas eminentemente casuísticos.

280 Além da obra citada na nota acima, ver, também, BOGDANY, A.; GOLDMANN, M. Sovereign Debt Restructurings as Exercises of International Public Authority. In: ESPÓSITO, C.; LI, Y.; BOHOSLAVSKY, J. Sovereign Financing and International Law: the UNCTAD Principles on Responsible Sovereign Lending and Borrowing. Oxford: Oxford University Press, 2013, p. 57. 


\subsection{A REESTRUTURAÇÃO DA DÍVIDA MULTILATERAL}

Categoria da dívida pública habitualmente excluída das operações de reestruturação é aquela assumida perante organizaçôes internacionais, algo que se origina a partir da posição privilegiada que esses entes alegadamente apresentam em comparação com os demais credores do Estado. Em termos mais concretos, os compromissos perante organismos financeiros multilaterais não se incluem entre aqueles cujos termos de pagamento serão redefinidos a partir de alguma oferta de renegociação, e são, na maior parte das vezes, expressamente excluídos da oferta, pelo que seus pagamentos não serão alterados. Esta característica da dívida multilateral, que poderia ser sintetizada em sua irrenegociabilidade, se origina fundamentalmente de determinados elementos da prática dos Estados, mas também do comportamento dos outros tipos de credores, que os colocam fora de contestação. Os fundamentos jurídicos deste benefício não são, porém, uniformemente percebidos.

\subsubsection{As organizações internacionais como credores privilegiados}

Ao ocorrer uma crise de proporções relevantes em decorrência da suspensão do serviço da dívida pública externa de algum país, os acordos em torno da reestruturação dos pagamentos podem ser compreendidos como uma expressão da solidariedade internacional, a qual se opõe a iniciativas unilaterais quer dos devedores, quer dos credores. ${ }^{281}$ Este caminho interpretativo não esconde, entretanto, que a ideia de solidariedade se concretiza a partir de uma conjunção de interesses em torno da estabilidade do sistema financeiro internacional, ameaçada pela concretização dos riscos de crédito. ${ }^{282}$ Daí que, principalmente a partir das graves crises da década de 1980, a solução às sucessivas tensões sobre o cumprimento de obrigaçôes financeiras externas tenha se dado de forma negociada, como já visto, e que as conversóes consensuais tenham tomado forma entre o Estado e seus credores. A dívida suscetível de reestruturação não é, contudo, objeto de operações uniformes, e alguns credores, tais como as instituições financeiras internacionais,

281 Segundo L. Focsaneanu, "la solidarité s'est manifestée par la restructuration et le refinancement de la dette extérieure des pays débiteurs" (Endettement extérieur, renégotiation des dettes, controle Du crédit transnational. Revue Gnénérale de Droit International Public, Paris, vol. n. 2, 1985, p. 305). Ver, também, JOBLIN, J. Les Rouages de l'Economie Mondiale au Regard de l'Ethique. Application au Probleme de la Dette. Le point de Vue de l'Eglise. In: VIADEL, A. C.; MONTORO, A. F. La Deuda Externa: Dimensión Política y Jurídica. Madri: Iepala Editorial, 1999, p. 233.

${ }^{282}$ Neste sentido, Espinosa de los Monteros, R. Z. Les Dettes Publiques des Etats à l'Egard des Organisations Internationales. In: CARREAU, D.; SHAW, M. (Coord.). La Dette Extérieure. Haia: Martinus Nijhoff Publishers, 1995, p. 259. 
continuam a ser pagas de acordo com os termos originais. É neste sentido que se pode falar de um tratamento privilegiado dos organismos internacionais, que se beneficiam da exclusão de seus créditos dos processos de reestruturação. $\mathrm{O}$ que chama a atenção é que este benefício do adimplemento das obrigações contém uma fraca previsão jurídica em normas convencionais, normalmente aquelas deitadas em documentos constitutivos de instituições financeiras das quais o Estado faça parte e aos quais, pelo regular procedimento de adesão à organização, se vincula. Fraca, porque o mesmo tipo de cláusula presente em outros documentos relativos a outros credores não foi razão suficiente para que lhes fosse concedido o mesmo isolamento dos efeitos da moratória de eventual moratória. O fato de que o privilégio seja efetivamente observado em relação a organismos financeiros internacionais estimula o surgimento de questóes sobre a fonte jurídica de normatividade deste comportamento reiterado. O costume desponta como uma possível resposta, para a qual relevam a análise da prática e da opinio juris.

O comportamento dos diversos agentes envolvidos em processos de reestruturação indica uma percepção uniforme sobre a prioridade dos reembolsos a organizaçôes internacionais. Da parte dos Estados, as duas principais instâncias de promoção do diálogo com os credores não se ocupam diretamente da dívida multilateral. Tanto as reunióes no Clube de Paris como os encontros com os comitês representantes dos bancos comerciais tratam de operações financeiras bilaterais e comerciais, respectivamente, não partilham a competência para renegociar a dívida multilateral. ${ }^{283} \mathrm{~A}$ seu turno, ainda que as partes mais interessadas, as instituições financeiras internacionais propriamente, acompanhem as reuniões do Clube de Paris e participem dos acordos firmados a partir das tratativas do Clube de Londres, há uma sistemática recusa de proceder à revisão de suas próprias obrigações. ${ }^{284}$ Esta é uma linha de conduta persistente desde que a Liga das Nações, em 1930, afirmou explicitamente a prioridade dos empréstimos que concedia em razão de constituírem uma ferramenta primordial para o aparato financeiro de que dispunha a organização para estimular a recuperação econômica e a reconstrução dos países-membros. Ainda que as características dos instrumentos de financiamento da Liga fossem distintas daquelas adotadas atualmente por organismos globais

283 Cf. VILANOVA, J. C.; MARTIN, M. The Paris Club. Londres: Debt Relief International, 2001; HUDES, K. Coordination of Paris and London Club Reschedulings. In: BRADLOW, D (coord.). International Borrowing: Negotiating and Structuring International Debt Transactions. 2. ed. Washington, D.C.: International Law Institute, 1986.

${ }^{284}$ ESPINOSA DE LOS MONTEROS, R. Z. Les Dettes Publiques des Etats à l'Egard des Organisations Internationales. In: CARREAU, D.; SHAW, M. (Coord.). La Dette Extérieure. Haia: Martinus Nijhoff Publishers, 1995, p. 261. 
como o FMI, ${ }^{285}$ aí se afirmou a precedência dos créditos das instituições financeiras globais como uma questão essencial para a continuidade de seu funcionamento e para que as arestas nos pagamentos não prejudicassem terceiros Estados que se beneficiassem de programas levados a cabo por essas organizações.

Com base neste princípio, as dívidas do Estado com o FMI e outros entes com funções financeiras são raramente renegociadas. No âmbito do Fundo, essas obrigaçôes se originam, com maior frequência, de programas de assistência conduzidos em conjunto com o Banco Mundial firmados mediante o compromisso de ajustes estruturais pelos países beneficiários. Quando se trata de obtenção de liquidez para enfrentar crises na balança de pagamentos, o que costuma ser o uso mais frequente dos recursos do Fundo, após transcorrido o período de uso o Estado-membro se compromete com a recompra da moeda que pagou ao Fundo em troca das divisas que lhe foram colocadas à disposição. ${ }^{286} \mathrm{O}$ acordo constitutivo do FMI prevê, no artigo IX, que seus pagamentos ficam excluídos dos efeitos suspensivos de uma declaração de moratória, e o mesmo faz o estatuto do Banco Internacional para a Reconstrução e o Desenvolvimento. ${ }^{287}$ A sustentação desta imunidade às moratórias se apresenta como uma medida de salvaguarda de sua liquidez financeira, a qual, se afetada, recairia sobre todos os países-membros da organização. $\mathrm{O}$ default perante o organismo financeiro seria, assim, um default perante toda a comunidade internacional, à medida que reduzisse o volume de recursos disponíveis para o cumprimento de suas funçôes.

Esta percepção de um dever de solidariedade internacional desponta não apenas na reiterada prática dos Estados, cujos interesses na liquidez de uma instituição como o FMI são de fácil identificação, mas no comportamento dos próprios bancos comerciais, que não a contestam. Isso porque nem mesmo os Estados mais endividados costumam suspender os pagamentos às instituiçôes financeiras internacionais e,

285 Sobre as características da ação financeira da Liga das Naçôes e o contraste com os instrumentos de ação das atuais instituições multilaterais como o FMI, ver FLORES, J.; DECORZANT, Y. Public Borrowing in Harsh Times: the League of Nations Loans Revisited. Working Paper Series, Universidade de Genebra, Genebra, n. 12091, set. 2012.

286 WOOD, P. Debt Priorities in Sovereign Insolvency. International Financial Law Review, Londres, vol. 1, n. 7, nov. 1982, p. 8.

287 Segundo o artigo IX, Seção 6, do acordo constitutivo do Fundo Monetário Internacional, “(...) all properties and assets of the Fund shall be free from restrictions, regulations, control and moratoria of any nature." (FMI. Articles of Agreement of the International Monetary Fund (1944). Washington, D.C.: FMI, 2011, p. 27). O acordo constitutivo do Banco Mundial tem identical redação no artigo VII, seção 6 (cf. BIRD. Articles of Agreement of the International Bank for Reconstruction and Development. Washington, D.C.: BIRD, 2012, p. 17). 
em segundo lugar, os interesses bancários confluem para a busca de fórmulas de reestruturação que lhes permita preservar os próprios balanços, para cuja conclusão a intermediação da organização internacional credora do Estado tem um importante papel a desempenhar. O crédito privilegiado não chega a constituir, portanto, matéria de larga controvérsia; ao contrário, observa-se algum grau de acomodação ao benefício, a partir do qual se cogita do surgimento de um costume internacional orientador da juridicidade dessa prática. ${ }^{288}$

Há, entretanto, uma distância considerável entre a apontada conjunção de interesses e a existência de uma percepção subjetiva da normatividade do privilégio creditício das instituições financeiras internacionais. A análise dos atos constitutivos dos mais importantes desses organismos oferece um diversificado panorama de seu modo de agir quando em confronto com a suspensão efetiva ou potencial dos pagamentos por um Estado devedor. Os estatutos apontam, com maior ou menor flexibilidade, para a admissão da possibilidade de modificação das condições de pagamento da dívida multilateral, e esta permissão de flexibilidade, ainda que pouco aplicada, vai em sentido contrário à ideia de uma norma costumeira que obrigue aos pagamentos mesmo quando outros credores são afetados pela sua suspensão. É o que se nota quanto aos principais bancos de desenvolvimento: a ideia de que a dívida multilateral pode ter seus termos modificados não é estranha às normas internas desses organismos. No Banco Interamericano de Desenvolvimento (BID), é prevista a adoção de medidas oportunas em vista da modificação das condições dos empréstimos, com exceção da modificação da moeda de reembolso. ${ }^{289}$ No mesmo sentido vão as normas internas do $\mathrm{BIRD}^{290}$ e do Banco Europeu para

288 FAU-NOUGARET, M. La Liaison Infernale: Conditionnalité Democratique et Dette des Etats à l'Egard des Organizations Internationales. Civilizar Ciencias Sociales y Humanas, Bogotá, vol. 8, n. 15, jul.-dez. 2008, p. 56.

${ }^{289}$ É prevista a expulsão do membro inadimplemente pelo artigo IX, seção 2, mas admite-se a modificação do acordo financeiro no artigo VII, seção 3, letra "a”, segundo o qual "[t]he Bank, in the event of actual or threatened default on loans made or guaranteed by the Bank using its ordinary capital resources, shall take such action as it deems appropriate with respect to modifying the terms of the loan, other than the currency of repayment." (BID. Agreement Establishing the Inter-American Development Bank. Washington, D.C.: BID, 1959, p. 20-27).

290 Artigo IV, seção 7: “[i] n cases of default on loans made, participated in, or guaranteed by the Bank: (a) The Bank shall make such arrangements as may be feasible to adjust the obligations under the loans, including arrangements under or analogous to those provided in Section 4 (c) of this Article; (...) (c) Whenever necessary to meet contractual payments of interest, other charges or amortization on the Bank's own borrowings, or to meet the Bank's liabilities with respect to similar payments on loans guaranteed by it, the Bank may call an appropriate 
Reconstrução e Desenvolvimento (BERD) ${ }^{291}$ As exceções são os Bancos Asiático e Africano de Desenvolvimento, ${ }^{292}$ que, em vez de medidas de ajuste, preveem unicamente a sanção da expulsão do país membro inadimplemento. O Banco de Compensações Internacionais, por fim, a despeito de ser silente a respeito de medidas modificativas dos acordos diante da inexecução de seus créditos, tem demonstrado maior maleabilidade do que a linguagem sucinta de seu estatuto deixaria entrever. ${ }^{293}$

Medidas alternativas à expulsão da organização financeira internacional se encontram também na principal delas, o FMI. Seu acordo constitutivo merece maior atenção não apenas em razão da importância da instituição, mas também por ser mais específico a respeito da inexecução dos pagamentos da dívida multilateral, oferecendo possibilidades sancionatórias gradativas. O sistema de sanções do Fundo tornou-se mais refinado em comparação com outros cujos mecanismos se

amount of the unpaid subscriptions of members in accordance with Article II, Sections 5 and 7. Moreover, if it believes that a default may be of long duration, the Bank may call an additional amount of such unpaid subscriptions not to exceed in any one year one percent of the total subscriptions of the members for the following purposes: (i) [t]o redeem prior to maturity, or otherwise discharge its liability on, all or part of the outstanding principal of any loan guaranteed by it in respect of which the debtor is in default; (ii) [t] o repurchase, or otherwise discharge its liability on, all or part of its own outstanding borrowings." (BIRD. Articles of Agreement of the International Bank for Reconstruction and Development. Washington, D.C.: BIRD, 2012, p. 10).

291 Artigo 17.1: “[i]n the Bank's ordinary operations, in case of arrears or default on loans made, participated in, or guaranteed by the Bank, and in cases of losses or underwriting and in equity investment, the Bank shall take such action as it deems appropriate." (BERD. Agreement Establishing the European Bank for Reconstruction and Developement. Paris, 1991).

${ }^{292}$ No caso do Banco Asiático, dispõe o artigo 42.1 que "[i]f a member fails to fulfill any of its obligation to the Bank, the Board of Governors may suspend such member by a vote of two-thirds of the total number of Governors, representing not less than three-fourths of the total voting power of the members" (ADB. Agreement Establishing the Asian Developement Bank. Manila, 1966). O artigo 44 do acordo que estabelece o Banco Africano tem redação similar (cf. AfDB. Agreement Establishing the African Development Bank. Cartum, 1963).

293 O artigo 25 prevê que o banco deve ser administrado com vistas a manter sua liquidez. No original, " $[\mathrm{t}]$ he Bank shall be administered with particular regard to maintaining its liquidity, and for this purpose shall retain assets appropriate to the maturity and character of its liabilities" (BIS. Statutes of the Bank for International Settlements. Basileia, 1930). A amplitude deste dispositivo tem servido para que o banco, efetivamente, tome as medidas que considerar necessárias para a manutenção de sua liquidez, o que pode envolver a modificação das obrigações dos Estados-membros. Cf. ESPINOSA DE LOS MONTEROS, R. Z. Les Dettes Publiques des Etats à l'Egard des Organisations Internationales. In: CARREAU, D.; SHAW, M. (Coord.). La Dette Extérieure. Haia: Martinus Nijhoff Publishers, 1995, p. 264-265. 
concentram na expulsão dos Estados inadimplentes, aperfeiçoamento ocorrido a partir de 1990 com a estratégia de ampliação geral da liquidez. ${ }^{294}$ As alterações estatutárias se dirigiram ao artigo 26 do acordo constitutivo, que, na redação anterior, previa duas espécies de sanções complementares ao Estado que se encontrasse em mora com o organismo. A primeira delas seria o bloqueio do acesso aos recursos do Fundo, a qual se insere entre aquelas sanções classificáveis como negação de benefícios. ${ }^{295}$ Apenas diante do prolongamento da inexecução (fala-se, no acordo, em atraso razoável) é que o Estado poderia ser chamado a se retirar - sanção aplicada uma única vez na história do FMI, contra a Tchecoslováquia em 1954, que havia sido também suspensa do Banco Mundial no ano anterior em razão do descumprimento persistente de deveres com estas instituições. ${ }^{296}$ A primeira das penalidades - a vedação ao recebimento de recursos - era também considerada uma medida excepcional, e sua aplicação começou a ser feita apenas da segunda metade dos anos de 1980 em diante, de forma sistemática, o que indicava a degradação do ambiente de cooperação financeira internacional diante das dificuldades econômicas dos Estados-membros do Fundo, particularmente os africanos e latino-americanos. ${ }^{297}$

As discussões sobre as alterações do direito interno dessa organização se voltaram, então, a oferecer maiores possibilidades de gradação entre as sanções aplicáveis, pelo que, com a terceira emenda ao acordo constitutivo do FMI, que data de 11 de novembro de 1992, se incluiu um terceiro grupo de sanções relativas à suspensão do direito de voto, emprestando ao artigo 26 sua feição atual, que se refere, na seção 2 , aos membros que persistam no descumprimento das obrigações. ${ }^{298} \mathrm{O}$

${ }^{294}$ Ver FMI. Resolução n. 45-2, de 28 de junho de 1990. Washington, D.C., 1990.

295 GOLD, J. The "Sanctions" of the International Monetary Fund. Virginia Journal of International Law, Charlottesville, vol. 66, n. 5, out. 1972, p. 744-745.

296 Ver MAGLIVERAS, K. Exclusion from Participation in International Organizations: the Law and Practice behing Member States' Expulsion and Suspension of Membership. Haia: Kluwer Law, 1999, p. 183.

297 ESPINOSA DE LOS MONTEROS, R. Z. Les Dettes Publiques des Etats à l'Egard des Organisations Internationales. In: CARREAU, D.; SHAW, M. (Coord.). La Dette Extérieure. Haia: Martinus Nijhoff Publishers, 1995, p. 268.

298 O texto do artigo 26, seção 2, é este: “(a) If a member fails to fulfill any of its obligations under this Agreement, the Fund may declare the member ineligible to use the general resources of the Fund. Nothing in this Section shall be deemed to limit the provisions of Article V, Section 5 or Article VI, Section 1. (b) If, after the expiration of a reasonable period following a declaration of ineligibility under (a) above, the member persists in its failure to fulfill any of its obligations under this Agreement, the Fund may, by a seventy percent majority of the total voting power, suspend the voting rights of the member. During the period of the suspension, 
novo poder de suspensão foi então incluído no sistema sancionatório binário anterior e requer maioria de $70 \%$ dos membros do Comitê Executivo com direito a voto. As consequências da suspensão são especificadas no Anexo L do acordo, e, ainda que complexas em seus detalhes, consistem na proibição de deliberar sobre as propostas de emenda ao acordo constitutivo, na preclusão de deliberar sobre a escolha dos membros dos comitês executivo e diretor, na suspensão do direito de voto nos órgãos deliberativos, e na exclusão do membro nacional do Estado suspenso que faça parte dos comitês diretivos (a não ser que tenha sido eleito por dois terços dos votos de outros países-membros). O Estado ainda preserva, no entanto, o direito de enviar representantes aos Comitês Diretor e Executivo se a matéria em deliberação for de seu particular interesse. ${ }^{299}$

A terceira emenda se relaciona diretamente com o aumento das quotas promovido no início dos anos de 1990 e representou uma solução de compromisso a respeito de duas visões distintas sobre as funções do Fundo. A primeira delas, mais expansiva, era a de que as transferências de recursos deveriam servir de veículo para a correção de desequilíbrios da ordem econômica internacional, com o que os empréstimos deveriam assumir características mais concessivas às necessidades de países em desenvolvimento, até mesmo com o apoio à reestruturação da dívida multilateral. Esta estratégia, conhecida como a de "ajustes simétricos", exigiria também dos países desenvolvidos, que não recorrem usualmente aos recursos do Fundo, adaptaçôes às condicionalidades colocadas para os países em desenvolvimento, com medidas de ajustes econômicos e financeiros semelhantes. Essa perspectiva contrasta fortemente com alguma eventual regra internacional de não reestruturação da dívida multilateral ao colocar em evidência a possibilidade de modificações das obrigações financeiras com o Fundo, desde que produzissem situação menos gravosa para o Estado devedor.

Uma segunda visão sobre o papel do FMI na nova conjuntura internacional dos anos 90 se caracterizaria por ser mais restritiva, e propunha que o organismo

the provisions of Schedule L shall apply. The Fund may, by a seventy percent majority of the total voting power, terminate the suspension at any time. (c) If, after the expiration of a reasonable period following a decision of suspension under (b) above, the member persists in its failure to fulfill any of its obligations under this Agreement, that member may be required to withdraw from membership in the Fund by a decision of the Board of Governors carried by a majority of the Governors having eighty-five percent of the total voting power." (FMI. Articles of Agreement of the International Monetary Fund (1944). Washington, D.C.: FMI, 2011, p. 56-57).

${ }^{299}$ FMI. Articles of Agreement of the International Monetary Fund (1944). Washington, D.C.: FMI, 2011, p. 84-85. 
continuasse com os programas de oferecimento de liquidez para alívios econômicos e financeiros temporários, mas que não se mobilizasse diretamente em direção a políticas de transferências e correçóes de desequilíbrios de renda entre os Estados. Nesta direção, programas de alívio do endividamento seriam desaconselhados por punirem economias mais sólidas em favor de outras levadas à crise pela condução de políticas econômicas menos recomendáveis. ${ }^{300} \mathrm{~A}$ função de coordenação de negociações econômicas entre os países se desenvolveria, então, em outros fóruns, tais como o Grupo dos 7, e não no interior do próprio Fundo.

A distância entre essas duas interpretações se reduziu com a maior atuação do FMI nas negociaçôes entre Estados devedores e credores, promovendo cortes nos encargos da dívida pública ao mesmo tempo em que se aplicavam condicionalidades e se recomendavam ajustes econômicos aos países em descumprimento de suas obrigações. A política de ampliação das quotas, que elevaria o volume de recursos disponíveis para os países em desenvolvimento, foi negociada em direta conexão com a aprovação da terceira emenda ao acordo constitutivo. Uma maior disponibilidade de crédito internacional para momentos de crises de liquidez teria que ser acompanhada de medidas sancionatórias mais adaptáveis para assegurar a estabilidade das expectativas de retorno do Fundo, e outros programas voltados a distorções estruturais passariam pela discussão sobre os cancelamentos da dívida pública. A terceira emenda representou uma reação aos crescentes casos de inexecução das obrigações financeiras, nos quais o Fundo passaria a ter maior presença como instância de coordenação de interesses entre as diversas partes, com a promoção de algumas medidas de alívio do endividamento. Estas iniciativas passariam a se aplicar a terceiras partes, mas também às próprias obrigações em que o FMI figurasse como credor.

Como se pode notar, a prática de não renegociar a dívida multilateral está mais ligada à preservação da reputação do crédito do Estado e à manutenção das linhas de fluxos de financiamento por parte de instituições multilaterais do que a qualquer impossibilidade jurídica, o que evidencia uma decisão econômica usual, mas não um direito internacional costumeiro; uma política econômica estratégica, mas não uma norma cogente. As cartas das instituições financeiras globais e regionais reconhecem, em extensões variáveis, que as arestas financeiras da dívida multilateral podem exigir modificações dos acordos, e no mais relevante dos casos, o

300 Para a literatura mais relevante sobre ambas as perspectivas, ver HEAD, J. Suspension of Debtor Countries' Voting Rights in the IMF: an Assessment of the Third Amendment to the IMF Charter. Virginia Journal of International Law, Charlottesville, vol. 33, n. 3, 1993 , p. $635-640$. 
do FMI, não apenas se discutiu a possibilidade de reestruturação das obrigações das quais é credor, mas foram criados programas especificamente voltados à redução das obrigações financeiras de países de menor renda. O principal destes programas é a Iniciativa HIPC, sigla que designa os países pobres altamente endividados (heavily indebted poor countries).

\subsubsection{O perdão multilateral da dívida pública: a iniciativa HIPC}

Outra prática frequente, mas pouco disciplinada, das relaçôes financeiras entre os Estados é o perdão da dívida pública, isto é, o cancelamento, pelo credor, dos valores devidos pelo Estado. Tratando-se de ato unilateral do credor, sua natureza é voluntária, ainda que adotada diante de circunstâncias econômicas prementes, tais como a iminência de uma declaração de moratória ou a impossibilidade de pagamento integral. Do ponto de vista dos credores privados, o perdão se dá no contexto das propostas negociais de reestruturação da dívida. Há, de outro lado, formas de inexecução consentida da dívida pública que se dão perante credores oficiais do Estado (outros Estados e organizaçôes internacionais) pelas vias institucionais de acordos multilaterais.

O tema é intimamente ligado ao direito ao desenvolvimento, por se dirigir aos encargos financeiros de países menos desenvolvidos que são colocados em situação econômica crítica pela continuidade do serviço da dívida. Durante os preparativos para a Segunda Década do Desenvolvimento, formou-se a Comissão do Desenvolvimento Internacional, em 1968, que teria grande impacto sobre as metas de desenvolvimento estabelecidas pelas Nações Unidas. Um dos principais assuntos investigados pela Comissão era o problema do crescente endividamento público e a sequência de crises daí resultantes durante os anos de 1950 e 1960. A partir da conclusão de que os procedimentos e princípios para o alívio das elevadas cargas de endividamento público eram frequentemente inadequados, a Comissão recomendou que se afastasse a abordagem de curto prazo em favor de novas estratégias voltadas, preferencialmente, a evitar que os reescalonamentos das dívidas ocorressem com habitualidade, e que os programas internacionais de redução da dívida se transformassem em uma forma legítima de auxílio e cooperação internacional, permitindo novos empréstimos para o refinanciamento dos pagamentos da dívida externa de forma a evitar as reestruturações de grande escala. ${ }^{301} \mathrm{O}$ alívio da dívida dos países em desenvolvimento recebeu forte incentivo da campanha do Jubileu

301 RIEFFEL, L. Restructuring Sovereign Debt: the Case for Ad Hoc Machinery. Washington, D.C.: Brookings Institution Press, 2003, p. 1617. 
2000, uma coalizão de nações articulada com as Metas de Desenvolvimento do Milênio da Organização das Nações Unidas. A iniciativa foi louvada, com tom elevadamente otimista, como uma das mais promissoras para o combate à pobreza, ${ }^{302}$ com o apoio de lideranças políticas e artísticas ${ }^{303}$ e o aporte intelectual de importantes economistas que apontaram os programas de alívio da dívida como um imperativo tanto moral como econômico. ${ }^{304} \mathrm{~A}$ institucionalização das reduções do endividamento público de países em crítica situação econômica e social se concretizou pela chamada Iniciativa HIPC. Esse programa, porém, lança raízes sobre necessidades anteriores à sua criação oficial.

A redução do endividamento como política de promoção do desenvolvimento já era tema presente nas cúpulas econômicas do Grupo dos 7 na década de 1980. A tendência se manteve nestes encontros durante os anos seguintes. Há, para isso, um motivo de índole pragmática. Desde que os problemas de reembolso dos empréstimos públicos se tornaram sistemicamente relevantes no final dos anos de 1970, foi preciso formular alternativas para o serviço da dívida de países de mais baixa capacidade financeira que enfrentavam ou estavam na iminência de enfrentar crises inicialmente percebidas como de liquidez. ${ }^{305}$ As primeiras propostas oficiais se concentravam em redefinir os prazos de pagamento e em oferecer novos empréstimos em condições mais favoráveis. Em troca do alívio financeiro representado pela redução dos pagamentos, as ofertas se articulavam com programas de ajuste estrutural nos termos e sob o monitoramento do FMI. Assim, se multiplicaram os pedidos para instauração de foros de renegociação da dívida bilateral no âmbito do Clube de Paris, os quais provinham, em sua maior parte, da África. ${ }^{306}$

302 BIRDSALL, N.; WILLIAMSON, J.; DEESE, B. Delivering on Debt Relief: From IMF Gold to a New Aid Architecture. Washington, D.C.: Center for Global Development, 2002, p. 1.

303 Sobre o impulso moral da iniciativa (bem como sobre o evento que reuniu o Papa, Bono Vox e Dalai Lama), ver BUSBY, J. Bono Made Jesse Helms Cry: Jubilee 2000, Debt Relief, and Moral Action in International Politics. International Studies Quarterly, Washington, D.C., vol. 51, p. 247-275.

${ }^{304}$ KRUGMAN, P. Debt Relief is Cheap. Foreign Policy, Washington, D.C., n. 80, 1990, p. 141-152.

305 DASEKING, C.; POWELL, R. From Toronto Terms to HIPC Initiative: a Brief History of Debt Relief for Low-Income Countries. IMF Working Paper, Washington, D.C., n. 99, out. 1999 , p. 3.

306 No período aqui considerado, as solicitações foram feitas pela República Centro-Africana, República Democrática do Congo, Libéria, Senegal, Serra Leoa, Sudão, Togo e Uganda (GAMARRA et al. Debt Relif and Sustainability. In: NAÇÕES UNIDAS. Realizing the Right to Development: Essays in Commemoration of 25 Year of the United Nations Declaration on the Right to Development. Nova Iorque: OHCHR, 2013, p. 277). 
Estas primeiras iniciativas, porém, se mostraram insuficientes com o agravamento das condições de pagamento nos anos seguintes, quando proliferaram crises que se mostraram mais profundas do que temporários problemas de disposição de meios de pagamento. Em vez de dificuldades de liquidez, as crises dos países em desenvolvimento latino-americanos evidenciaram uma situação mais complexa, para cuja solução iniciativas mais arrojadas precisavam ser postas em prática. Esta agenda consideraria como relevantes não apenas as necessidades de ajuste, mas também sua conciliação com a recuperação econômica e a retomada do crescimento. Não bastaria calcular os descontos mínimos necessários para atender ao serviço da dívida vincenda sem que se adotassem medidas preventivas de futuras necessidades de reestruturação. A abordagem então revista era aquela pautada por critérios imediatos de cálculo dos descontos necessários para não interromper o serviço da dívida, técnica de reestruturação adotada pelo Clube de Paris para a chamada dívida não concessional, isto é, as obrigações cujos prazos de pagamento e taxas de juros não se houvessem dado no interior de algum programa de assistência bilateral. ${ }^{307}$ As características dos procedimentos de reestruturação nos Clubes de Paris e Londres serão tema do próximo capítulo, mas interesse destacar, aqui, que esta dívida com maturidade e juros definidos por critérios de mercado, cujo serviço era rediscutido nos sucessivos pedidos de renegociação do fim dos anos de 1970, não se mostrou suficiente para conter futuras crises da dívida pública, e se viu que o problema de seu serviço recomendava cautelas maiores com as condiçóes de recuperação do crescimento econômico. Do contrário novas renegociações seriam brevemente solicitadas.

A preocupação com estratégias mais amplas vinha, pois, a calhar diante da recorrência das renegociações, que muitas vezes envolviam países que já as haviam promovido em passado não muito distante. Em praticamente metade dos 55 acordos assinados com países africanos se observou a reestruturação de dívidas que já haviam sido previamente negociadas. O ponto mais importante dessa mudança de perspectiva foi o lançamento, no encontro anual do FMI com o Banco Mundial em 1987, da Parceria Estratégica com a África (SPA, em inglês Strategic Partnership with Africa). Ali se ofereceu uma moldura institucional para a ação coordenada da renegociação da dívida oficial de países africanos, e para isso abordava outras consideraçôes de crescimento para garantir a sustentabilidade econômica. Fixaram-se como critérios de elegibilidade para as medidas de alívio a baixa renda per capita, taxa de encargos do serviço da dívida em relação às exportações superior a $30 \%$ e

307 Cf. VILANOVA, J. C.; MARTIN, M. The Paris Club. Londres: Debt Relief International, 2001, p. 3. 
o compromisso com a adoção de ajustes macroeconômicos conforme recomendaçōes do FMI. O perdão da dívida africana foi a seguir incorporado ao instrumental do Clube de Paris, em conjunto com as negociações transcorridas no interior das reuniões do G-7. ${ }^{308}$

Se a iniciativa para a dívida africana representava uma abordagem estruturada para o alívio da dívida de países em desenvolvimento, os países credores e instituições multilaterais levariam a cabo novas políticas de enfrentamento das dificuldades financeiras globais diante da perspectiva de crises disseminadas de endividamento. O ano de 1987 foi marcado pelo plano de lançamento de empréstimos combinados com programas de assistência pelo FMI, o que ocorreu no encontro do G-7 em Veneza. Este serviço provido pelo Fundo, denominado Enhanced Structural Adjustment Facility (ESAF), partia da viabilidade de acomodaçôes financeiras mais favoráveis que as condiçōes de mercado para a dívida de países de mais baixa renda, com financiamento proveniente dos países desenvolvidos. Com a execução destes programas, se esperava recuperar a sustentabilidade da dívida pública e evitar que novos empréstimos a serem obtidos em condições normais de mercado (portanto mais onerosas) tivessem que ser disponibilizados em momento futuro para refinanciar uma dívida já anteriormente reestruturada. $\mathrm{O}$ recurso constante a novos créditos nestas condições indicaria níveis de endividamento persistentemente elevados diante dos quais os próprios credores, sem a expectativa de recuperar totalmente os capitais emprestados, apenas diante de recompensas excepcionais providenciariam novos capitais, com a elevação constante do estoque da dívida. Este é o chamado problema do sobre endividamento, ou debt overhang. ${ }^{309}$

Três propostas foram colocadas em discussão, ao fim da qual foram todas apresentadas como um menu de opções. A sugestão inglesa de taxas de juros reduzidas nos reescalonamentos, a proposta francesa de redução dos pagamentos vincendos em até um terço e reescalonamento do restante em condições normais de mercado, e a posição dos Estados Unidos, contrária às reduções do valor atual das obrigações, mas favorável ao alongamento dos prazos de maturidade, foram por fim apresentadas aos credores representados no Clube de Paris como um conjunto unificado de alternativas finalmente consolidadas na reunião do G7 do ano

308 Para as informações relativas à renegociação da dívida africana, v. GAMARRA et al. Debt Relif and Sustainability. In: NAÇÕES UNIDAS. Realizing the Right to Development: Essays in Commemoration of 25 Year of the United Nations Declaration on the Right to Development. Nova Iorque: OHCHR, 2013, p. 277.

309 Conferir, a respeito, KRUGMAN, P. Financing vs. Forgiving: a Debt Overhang. NBER Working Paper Series, Cambridge, n. 2486, 1988. 
seguinte, em Toronto. As três opções de renegociação ficaram então conhecidas como os "termos de Toronto", que marcaram as estratégias financeiras de reduções ou reescalonamentos com concessões dos credores ${ }^{310}$ Os desafios de consolidação de condições sustentáveis da dívida de países em desenvolvimento não seriam ainda plenamente enfrentados sem concessões ainda maiores, propostas em 1990 nos termos de Trinidad (reduções de até dois terços nos pagamentos a vencer), considerados muito ambiciosos pelos credores oficiais, e nos termos de Londres, de 1991, que previam concessionalidades de até $50 \%$ e a possibilidade de que, após um período de comprovação de bom desempenho econômico e políticas robustas, se discutisse a renegociação do estoque da dívida. Cancelamentos maiores puderam ser cogitados, no entanto, apenas em 1995, com a adoção dos termos de Nápoles, que admitiam concessões de até $67 \% .^{311}$

Esse modo de proceder compóe-se do instrumental financeiro que se aventou denominar como mecanismos tradicionais de alívio da dívida: reescalonamentos e reduções concessionais, isolados ou eventualmente combinados. A experiência com a dívida africana e as técnicas de reestruturação veiculadas nos termos dos encontros do G7, em conjunto com o FMI, os credores oficiais, membros do Clube de Paris, e comerciais não membros, foram incorporadas aos procedimentos da Iniciativa HIPC, lançada em 1996. Houve, no entanto, um elemento inovador em sua concepção, que foi o envolvimento de uma instituição financeira multilateral nos programas de alívio da dívida e correção do problema do sobre endividamento. Este escopo admitiria a renegociação da dívida multilateral para determinados países elegíveis às concessões financeiras do Fundo e do Banco Mundial. A primeira fase, também chamada de HIPC 1, exigia a condução de políticas macroeconômicas consideradas robustas por aquelas instituiçōes, para cuja avaliação concorriam diversos e complexos critérios, dentre os quais os níveis de sustentabilidade da dívida pública. Os empréstimos concessionais se atrelaram, portanto, ao cumprimento das condicionalidades. Entre estas condições, a conclusão de acordos com os credores no âmbito do Clube de Paris que assegurassem fluxo constante de pagamentos do serviço da dívida oficial e o cumprimento dos compromissos assumidos com o FMI, em obediência ao reescalonamento concedido. Uma fórmula de simplificação

310 DASEKING, C.; POWELL, R. From Toronto Terms to the HIPC Initiative: a Brief History of Debt Relief for Low-Income Countries. IMF Working Paper,Washington, D.C., n. 142, out. 1999, p. 9.

311 SCHNEIDER, B. Clubbing in Paris: Is Debt Sustainability an Illusion? In: STIGLITZ, J.; OCAMPO, J. A. (Org.). Sovereign Debt Workouts. Nova Iorque: Columbia University Press, 2007. 
destes acordos permitiria resumi-los em um compromisso com o fluxo de pagamentos da dívida reescalonada, ou flow-rescheduling agreement, a ser obtido no Clube de Paris em apoio ao cumprimento do programa compromissado com o FMI e o Banco Mundial. Haveria, ainda, outros dois requisitos: que o país beneficiário buscasse termos concessionais semelhantes com outros credores não membros do Clube de Paris e demais credores privados e que, além disso, encetasse negociações bilaterais com esses credores para o cancelamento da dívida no interior de algum programa de assistência válido de parte a parte. ${ }^{312}$ Apenas com o cumprimento destes requisitos, que assegurariam a sustentabilidade do serviço da dívida pública, é que um Estado de baixa renda per capita e nível elevado de endividamento poderia ser beneficiado por reduçôes de até $80 \%$ no valor corrente líquido de seu estoque de endividamento. ${ }^{313}$

Esses critérios se mostraram demasiadamente restritivos e morosos para readequar os níveis de endividamento dos países menos desenvolvidos elegíveis em tempo adequado. Como não fossem suficientes, os mecanismos de funcionamento da Iniciativa HIPC passaram por modificações discutidas na reunião do G7 de 1999, em Colônia, na Alemanha. A introdução da fase HIPC 2 lhe conferiria sua conformação atual, orientada por maior celeridade em relação ao período prévio e expansão do número de países elegíveis. Seus três objetivos, porém, são ainda tributários da fase anterior, com foco na sustentabilidade da dívida para que se vislumbrasse a permanente desnecessidade de futuros programas de alívio, no incentivo ao crescimento econômico por meio da superação do sobre endividamento, e, finalmente, na redução dos níveis de pobreza viabilizada pela liberação de recursos antes canalizados ao serviço da dívida. ${ }^{314} \mathrm{~A}$ ampliação dos países elegíveis se deu, em primeiro

312 Cf. ESQUIVEL, G.; LARRAÍN, F.; SACHS, J. The External Debt Problem in Central America: Honduras, Nicaragua and the HIPC Initiative. Development Discussion Papers, Harvard Institute for International Development, Cambrdige, n. 645, ago. 1998, p. 15-17.

313 A dívida seria considerada elevada, no âmbito da primeira fase da Iniciativa HIPC, caso a relação entre o valor corrente líquido e as exportações se situasse entre 200 e $250 \%$ (i) e a relação entre o valor corrente líquido e as receitas fiscais fosse maior do que $280 \%$ (ii). Além disso, seria necessário que as relações mínimas entre exportações e PIB (iii) e entre as receitas fiscais e o PIB (iv) fossem de $40 \%$ e $20 \%$, respectivamente (vide GAUTAM, M. Debt Relief for the Poorest: an OED Review of the HIPC Initiative. Washington, D.C.: The World Bank, 2003, p. 12).

314 G24. Heavily Indebt Poor Country (HIPC) Initiative. G24 Secretariat Briefing Paper, s.l., n. 2, mar. 2003; ISAR, S. Was the Highly Indebted Poor Country Initiative (HIPC) a Success? Consilience: The Journal of Sustainable Development, Nova Iorque, vol. 9, n. 1, 2012, p. 109-12. 
lugar, pela admissão de indicadores econômicos menos restritivos ${ }^{315}$ e pela divisão em duas etapas dos compromissos a serem executados para receber os cancelamentos. A decisão sobre as condições de sustentação dos encargos da dívida pública é guiada por um bom desempenho econômico durante o período de três anos, o qual se deve amparar, ainda, por programas de redução da pobreza. Um pacote de alívio da dívida será então elaborado. Caso estas medidas não sejam suficientes, procede-se à segunda etapa, que consiste em medidas adicionais com o apoio do FMI e do Banco Mundial. Se estas medidas forem eficazes, passa-se, então, ao ponto de finalização em que os credores participantes executam o compromisso de redução, nos limites definidos nos termos de Nápoles ou outros que o sucedam. ${ }^{316}$

Como se nota, a Iniciativa HIPC absorveu de forma mais clara, nesta segunda fase, a ideia que a orientou desde o primeiro momento, que é tornar a dívida de países de menor renda sustentável a partir de programas de alívio pautados por critérios objetivos. Além disso, o envolvimento de instituições financeiras internacionais mostrou que a concessão de cancelamentos à dívida multilateral não teria, caso se observassem os critérios objetivos e a adoção de condicionalidades, os efeitos desastrosos advogados pelos defensores de sua posição de credores privilegiados, mesmo que, no caso dos descontos oferecidos, estes não cheguem a volumes tão elevados quanto aqueles renegociados com credores bilaterais e comerciais. Além disso, instituições como o FMI têm à disposição meios de financiamento dos alívios concedidos que incluem suas próprias disponibilidades e as de outros entes, como o Banco Mundial e o BID. A solidez dos balanços do FMI, diretamente envolvido na Iniciativa HIPC, não foi assim comprometida por ela. ${ }^{317}$ A existência de normas internacionais de procedência costumeira sobre privilégio creditício é matéria, portanto, não consolidada, tendo em vista a evolução de iniciativas multilaterais de alívio da dívida que envolvem efetivas modificaçooes dos pagamentos da dívida multilateral no interior de programas de alívio.

Estas iniciativas apontam para um horizonte maior de envolvimento institucional na prevenção de crises potenciais da dívida pública, a partir de critérios

315 Com base nos indicadores expostos na nota 305, as relaçôes exigidas foram reduzidas para (i) $150 \%$, (ii) $250 \%$, (iii) $30 \%$ e (iv) $15 \%$ (cf. GAUTAM, M. Debt Relief for the Poorest: an OED Review of the HIPC Initiative. Washington, D.C.: The World Bank, 2003, p. 12).

316 MITCHELL, W.; GILMAN, M. Achievements to Date and Challenges Ahead: a View from the IMF. In: TEUNISSEN, J.; AKKERMAN, A. HIPC Debt Relief: Myths and Realities. Haia: FONDAD, 2004, p. 76.

317 MARTIN, M. Assessing the HIPC Initiative: the Key Police Debates. In: TEUNISSEN, J.; AKKERMAN, A. HIPC Debt Relief: Myths and Realities. Haia: FONDAD, 2004, p. 19-21. 
estabelecidos no âmbito de atuação dos programas relevantes. Seria ir longe demais, no entanto, supor um maior quadro de estabilidade jurídica dos mecanismos de resolução a partir de uma presumida consolidação de meios de ação eficazes pela Iniciativa HIPC. Isto porque muitos dos credores dos países pobres altamente endividados não fazem parte do Clube de Paris e se recusam a financiar reestruturaçôes de sua dívida pública com o oferecimento de concessões. Estes países podem ser divididos em cinco grupos: aqueles que não participam das instituições de Bretton Woods, Estados árabes e norte-africanos de renda média, grande parte dos países asiáticos (com a proeminência de China e Índia), países do Leste Europeu e, por razôes auto evidentes, outros países pobres altamente endividados. ${ }^{318}$

Finalmente, a Iniciativa HIPC não oferece e tampouco poderia oferecer, com seu mais limitado escopo de atuação, respostas para a litigiosidade de credores privados não participantes que decidam recorrer às vias judiciais para obter o reembolso integral e nos termos originais das obrigaçôes financeiras. Neste sentido se afirmou que a iniciativa poderia ser melhor classificada como um programa internacional de assistência financeira, e não como um mecanismo de resolução da dívida pública. ${ }^{319}$ Esta posição não deixa de ser congruente com a posição daqueles que, como Rieffel, são céticos a propósito das possibilidades de alguma forma de ação normativa multilateral na dinâmica internacional da dívida pública. A Iniciativa HIPC, contudo, além de demonstrar as possibilidades de atuação conjunta e organizada de Estados e instituições multilaterais no problema do sobre endividamento, os cancelamentos dos encargos negociados a partir de compromissos multilaterais avançam em diversas questões essenciais, entre as quais se destaca a incidência tanto sobre devedores como sobre credores das consequências de níveis elevados de dívida pública, com o subsequente compartilhamento de responsabilidades.

\subsection{A REESTRUTURAÇÃO DA DÍVIDA BILATERAL: O CLUBE DE PARIS}

Viu-se até aqui que organismos financeiros internacionais destinados à promoção da estabilidade e das condições de retomada do crescimento econômico por meio de investimentos se articulam muito proximamente com os debates globais sobre a dívida pública, e desempenham funções de grande relevância. As

318 MARTIN, M. Assessing the HIPC Initiative: the Key Police Debates. In: TEUNISSEN, J.; AKKERMAN, A. HIPC Debt Relief: Myths and Realities. Haia: FONDAD, 2004, p. 20.

319 RIEFFEL, L. Restructuring Sovereign Debt: the Case for Ad Hoc Machinery. Washington, D.C.: Brookings Institution Press, 2003, p. 2137. 
conversas entre Estados devedores e credores se desenvolvem, ainda, em outros grupos que se encarregam da condução das renegociações a partir de procedimentos previamente definidos, mesmo que esta definição seja significativamente informal. Os procedimentos para a resolução de crises internacionais da dívida pública, nos atuais mecanismos institucionais existentes, já foram comparados a um círculo de três anéis, em que o anel do centro representa as negociações de um governo com o FMI para a obtenção de financiamento à balança de pagamentos em troca de um programa estruturado de ajustes macroeconômicos. Entretanto, passada esta primeira fase, há ainda as arestas financeiras com outros credores, bilaterais e privados. Instituiu-se a praxe de que o segundo círculo ao qual se avança é o da reestruturação da dívida bilateral, em que se negociam condições mais vantajosas de pagamento com outros governos credores, e por fim o terceiro círculo da dívida pública perante entes privados, quando se articulam cancelamentos e novos empréstimos. ${ }^{320}$

O caso da dívida bilateral é emblemático a respeito das possibilidades de coordenação de interesses em direção a uma solução de controvérsias financeiras que ofereça uma resposta estável às divergências entre as partes. É bem verdade que, criado por uma necessidade circunstancial, o Clube de Paris - instância responsável pelas negociações da dívida pública com os principais credores oficiais -, não deve suas características de instância de negociação da dívida bilateral a um propósito explícito de institucionalização. As práticas iniciadas em 1956 com a reestruturação da dívida pública argentina perante alguns Estados europeus mostraram-se, no entanto, capazes de orientar as articulações de revisão dos pagamentos não apenas para aquele caso, mas para outros posteriormente surgidos, ${ }^{321}$ a ponto de quase todas as reestruturações da dívida bilateral terem transcorrido em seu âmbito. ${ }^{322} \mathrm{O}$ ponto de partida foram casos isolados, os quais lançaram um instrumental de ação que serviram para outros eventos individuais semelhantes. Assim, quando as arestas financeiras da dívida bancária começaram a se tornar um problema

320 RIEFFEL, A. The Role of the Paris Club in Managing Debt Problems. Essays in International Finance, Princeton, n. 161, dez. 1985, p. 2.

321 Cf. GRARD, L. Le Club de Paris et les Dettes Publiques des Etats. In: CARREAU, D.; SHAW, M. (Coord.). La Dette Extérieure. Haia: Martinus Nijhoff Publishers, 1995, p. 200.

322 Exceções foram a reestruturação das obrigações externas do Brasil nos anos de 1950 e 1960, que se passaram parcialmente no infrequente Clube de Haia, da Índia (1968 a 1977) e do Paquistão (1974 e 1981) e da Turquia perante um consórcio da OCDE (1959, 1965 e 1978-1980). Os casos são, porém, de pouca expressão em relação ao total de casos renegociados no Clube de Paris (cf. RIEFFEL, A. The Role of the Paris Club in Managing Debt Problems. Essays in International Finance, Princeton, n. 161, dez. 1985, p. 2-3). 
maior devido à maior participação dos empréstimos bancários no total do endividamento do Estado, na década de 1970, as técnicas de reestruturação da dívida bilateral já haviam sido estabelecidas com menos fluidez.

Uma instância dessa sorte, dedicada à renegociação da dívida bilateral, é guiada por um vetor normativo de atuação: a garantia de igualdade de tratamento tanto ao devedor como aos Estados credores. Isto porque, caso as tratativas escapassem a um fórum multilateral congregador das partes com interesses divergentes, as conversas exclusivamente bilaterais poderiam potencializar soluções divergentes e incompatíveis, afeitas às características próprias da dívida pública de país a país, o que não contribuiria para uma solução estável da controvérsia financeira. Essas características são ligadas aos fatores políticos que determinam a decisão de tomar e conceder empréstimos entre Estados, os quais não são os mesmos nos procedimentos que envolvem os credores privados. Neste caso, os objetivos de maximização dos lucros orientam a ação de instituições financeiras e demais particulares que decidem por conceder empréstimos ao Estado, e se permitem julgar por critérios de maior ou menor lucratividade; a dívida bilateral, por sua vez, nem sempre se orienta pelos mesmos parâmetros, pois, nos diferendos entre Estados, mesmo aqueles de fundamento financeiro, elementos propriamente políticos têm importância significativa. As negociações em instância multilateral têm a vantagem de permitir que elementos não econômicos da reestruturação da dívida bilateral, que produzem desequilíbrios nas posições relativas de poder em detrimento de interesses econômicos objetivamente considerados, tenham canais mais limitados de vazão. As vantagens que os procedimentos do Clube de Paris apresentaram à dívida bilateral residiriam, segundo Feldman, na criação de um ambiente mais receptivo aos elementos objetivos da reestruturação, o que se atingiria também por meio de prerrogativas equivalentes que todas as partes têm nas negociações, garantindo-se igual direito de participação. Assim, uma moldura multilateral avaliza, dadas as características de cada caso concreto, a igualdade formal de todos os Estados credores que se sentam à mesa de negociações, amortecendo o impacto das desigualdades de poder político de cada credor em relação ao devedor, ao mesmo tempo em que assegura a posição equivalente do devedor perante todos os seus credores. ${ }^{323}$

Os benefícios da posição equivalente dos credores nas renegociações podem ser apontados não apenas na igualdade formal garantida pela igualdade de direitos

${ }^{323}$ FELDMAN, H. Internationale Umschuldungen im 19. Und 20. Jahrhundert: eine Analyse ihrer Ursachen, Techniken und Grundprinzipien. Berlim: Duncker \& Humblot, 1991, p. 697-698. 
de participação, mas também nos incentivos para a coordenação de interesses, o que torna o resultado obtido ao final do processo a expressão do consenso multilateral e, portanto, menos passível de contestação. Potenciais conflitos decorrentes da percepção de tratamento desigual ficam, portanto, reduzidos. ${ }^{324}$ Caso as negociações se procedessem exclusivamente pela via bilateral, aqueles credores que se recusassem a oferecer concessões poderiam obter, contraditoriamente, vantagens em relação aos demais, pois o Estado, interessado em concluir a oferta de reestruturação, se veria estimulado a pagar um preço maior pela adesão do credor resistente. Assim, os recursos disponíveis para os credores que apresentaram maior receptividade à conversão de suas obrigaçooes seriam diminuídos em função de seu desvio ao credor que criou maiores dificuldades. $\mathrm{O}$ problema da ação coletiva será analisado mais adiante, especificamente em relação à dívida pública com credores privados, mas a não adesão de uma minoria de credores para a obtenção de vantagens em relação aos demais se observa, com características semelhantes, também na dívida pública em que o credor é outro Estado. ${ }^{325}$

Há, no Clube de Paris, um conjunto de regras estáveis ao longo do tempo para a reestruturação da dívida bilateral, as quais evidenciam um domínio jurídico não codificado e repousado sobre o modo contínuo de condução das renegociações. A primeira destas normas internas do Clube de Paris diz respeito a seu domínio material de ação, à competência ratione materiae, que se funda em regras estabelecidas desde a sua fundação, mas que se consolidaram a partir das crises dos anos 80 . Assim, a dívida sujeita à reestruturação levada ao Clube de Paris é a dívida dita pública, cuja definição apresenta algumas particularidades que devem ser observadas para dar início a um procedimento de renegociação neste foro. Isto porque o que ali se presta a qualificar a dívida como pública é a presença, na relação jurídica, de um Estado na posição de credor ou garantidor - a perspectiva relevante, portanto, é a do credor. No outro polo da relação jurídica é possível que figure também um Estado, algum de seus entes despersonalizados ou outras estruturas financeiras

324 Estima-se que, no caso da dívida bancária, conflitos entre os credores tenham levado, até aqui, a uma demora média de três meses para a implementação de acordos já concluídos. Cf. DAS, U.; PAPAIOANNOU, M.; TREBESCH, C. Sovereign Debt Restructurings 1950-2010: Literature Survey, Data, and Stylized Facts. Washington, D.C.: FMI, 2012, p. 17.

325 Para apresentação panorâmica do problema da ação coletiva como uma debilidade dos processos de reestruturação da dívida pública, ver SCHWARCZ, S. "Idiot's Guide” to Sovereign Debt Restructuring. Emory Law Journal, Atlanta, vol. 53, s. n., 2004. Sua presence na dívida bilateral, no entanto, é especificamente analisada, novamente, em FELDMAN, H. Internationale Umschuldungen im 19. und 20. Jahrhundert: eine Analyse ihrer Ursachen, Techniken und Grundprinzipien. Berlim: Duncker \& Humblot, 1991, p. 698. 
que desempenhem suas funções, tais como os fundos de desenvolvimento, porque assim se poderia classificar, em sentido estrito, a dívida como pública. Há no Clube de Paris, todavia, uma ampliação deste conceito para incluir em seu âmbito de ação também a renegociação das obrigações em que um Estado seja credor de entidades privadas garantidas pelo setor público, as quais serão tratadas como dívida pública. ${ }^{326}$ O Clube de Paris cobre, portanto, a dívida pública bilateral, e de sua competência ficam excluídas da dívida pública multilateral e as dívidas com entes privados não garantidas pelo setor público.

Esta competência material já foi mais ampla. Os primeiros casos levados ao Clube incluíam também obrigaçôes privadas cujos pagamentos se encontravam ameaçados porque o Estado em que se situava a empresa tomadora não lhe provia as divisas necessárias para realizar os pagamentos das obrigações em moeda estrangeira. Esta restrição monetária apenas seria motivo suficiente para levar um caso à negociação no Clube de Paris caso a moeda local não fosse uma moeda conversível, pelo exato motivo de que, adotando-se alguma forma de conversibilidade, o ente privado não poderia alegar a indisponibilidade da divisa. Esta possibilidade de acesso foi, no entanto, encerrada em 1985, em razão do crescimento de casos levados ao Clube, que passou a se concentrar de forma mais estrita na dívida que, segundo seus critérios, se qualifica como pública. ${ }^{327}$ Além disso, a dívida bilateral renegociável é apenas aquela de médio ou longo prazo, portanto a dívida consolidada; a dívida de curto prazo (isto é, aquela com prazo de vencimento inferior a um ano a partir da contratação) é usualmente afastada das renegociações como medida de preservação de alguma credibilidade financeira do Estado. ${ }^{328}$ Os pagamentos da dívida que, em algum momento, já tenham sido objeto de reescalonamento pelo próprio Clube, denominada PRD (previously rescheduled debt), são, a princípio, não têm prioridade nas renegociaçõos. ${ }^{329}$

O devedor que queira recorrer ao Clube de Paris para renegociar a dívida com credores oficiais deve obedecer a alguns requisitos, que dizem respeito a trabalhos

326 GRARD, L. Le Club de Paris et les Dettes Publiques des Etats. In: CARREAU, D.; SHAW, M. (Coord.). La Dette Extérieure. Haia: Martinus Nijhoff Publishers, 1995, p. 202.

327 GRARD, L. Le Club de Paris et les Dettes Publiques des Etats. In: CARREAU, D.; SHAW, M. (Coord.). La Dette Extérieure. Haia: Martinus Nijhoff Publishers, 1995, p. 202.

328 CARREAU, D. La Reestructuration de la Dette Publique des Etats au sein du Club de Paris. Annuaire Français de Droit International, vol. 36, n. 1, 1990, p. 660.

329 Sobre a abrangência dos acordos com países em desenvolvimento, que excluíram a PRD das renegociaçóes, ver os casos tratados em ROSS, D.; HARMSEN, R. Official Financing for Developing Countries. Washington, D.C.: FMI, 2001, p. 39 e seguintes. 
preparatórios e ao cumprimento de outros compromissos que demonstram a articulação do foro de renegociação da dívida bilateral com outras instituições multilaterais. Deve ser apresentado, assim: i) um memorando detalhado da situação macroeconômica que demonstre a incapacidade de atender ao objeto das obrigações financeiras bilaterais, com particular ênfase sobre a balança de pagamentos do país e os encargos representados pelo serviço da dívida pública; ii) um pedido bem delimitado sobre o tipo de alívio que se pretende obter, com a apresentação detalhada da composição do estoque da dívida pública; e iii) a implementação de programas de ajuste estrutural firmados com o FMI, etapa prévia à ação do Clube de Paris. ${ }^{330}$ A partir da fixação da competência e do cumprimento dos requisitos de abertura, os procedimentos de renegociação seguem-se de acordo com alguns princípios de ação consolidados na jurisprudência do Clube. São estes procedimentos que asseguram a essa entidade a característica de uma instância aplicadora de regras jurídicas válidas em seu âmbito interno, ainda que não se trate de uma organização internacional. Para isso seria necessária uma configuração formal da qual o Clube não dispõe. ${ }^{331}$

Os três princípios, ou três conceitos básicos, das reestruturações da dívida bilateral são a iminência do default, a condicionalidade e a repartição dos encargos. Nenhum deles foi referido expressamente nos primeiros vinte anos de atuação do Clube. Sua menção explícita apenas ocorreria como consequência do Diálogo Norte-Sul, que exigia a apresentação detalhada das características das futuras operações de renegociação da dívida pública dos países em desenvolvimento interessados. A documentação destes princípios foi procedida na 21a Sessão do Comitê de Comércio e Desenvolvimento da UNCTAD, sediada em Genebra em 1980. Foi apenas em 2001, porém, que o Clube de Paris se referiu, no lançamento de seu sítio na Internet, ${ }^{332}$ à aprovação daqueles critérios como princípios de seu funcionamento. ${ }^{333}$

330 VIlanOVA, J. C.; MARTIN, M. The Paris Club. Londres: Debt Relief International, 2001, p. 2.

331 "In short, the Paris Club is not an international organization. It represents a set of procedures currently used for negotiating arrangements to defer payment obligations on credits extended or guaranteed by creditor-country government agencies to both public-sector and private-sector borrowers in debtor countries unable to meet fully their external debt obligations" (RIEFFEL, A. The Role of the Paris Club in Managing Debt Problems. Essays in International Finance, Princeton, n. 161, dez. 1985, p. 3, grifo do autor).

332 www.clubdeparis.org

333 Cf. RIEFFEL, L. Restructuring Sovereign Debt: the Case for Ad Hoc Machinery. Washington, D.C.: Brookings Institution Press, 2003, p. 68. 
O primeiro desses princípios opera como uma defesa dos credores contra pedidos excessivos de alívio da dívida, os quais, deixados à exclusiva faculdade de agir do Estado devedor, podem representar uma alternativa vantajosa em comparação com outras medidas de política econômica que signifiquem maiores sacrifícios. Criou-se no Clube de Paris, então, a ideia segundo a qual os pedidos de reestruturação caprichosa não serão levados em consideração pelos credores. Para que se iniciem as rodadas de negociação se exigem demonstrações de que, na ausência das medidas de redução ou reescalonamento, o Estado devedor será levado a suspender os pagamentos, ou seja, será obrigado a declarar a moratória. Em um sistema internacional de crédito no qual as propostas de modificação das obrigações financeiras afetam a reputação do Estado, este critério estabelece a reestruturação como hipótese extrema, que apresenta como alternativa o default dos pagamentos. Demais, os credores se esforçam para evitar a impressão de que há critérios automáticos para as revisões dos pagamentos, aos quais o Estado possa recorrer sempre que se observar qualquer risco. $\mathrm{O}$ critério do default iminente reduz a solução da renegociação à hipótese terminal de ausência de outras alternativas. ${ }^{334}$

O teste da iminência da moratória geralmente toma por base a existência de uma lacuna de financiamento ex ante (ex ante financing gap), o que é aferido por uma de duas técnicas de verificação. A primeira delas é que já existam obrigações financeiras em situação de inexecução; a segunda que, com base em prospecçôes do FMI, as necessidades de divisas para um ano futuro excedam os recursos disponíveis. ${ }^{335}$ Neste último caso, realiza-se a análise ex ante da balança de pagamentos, o que é alvo de certa crítica devido à falibilidade dos métodos disponíveis de mensuração. ${ }^{336}$ Independentemente dos instrumentos analíticos que permitem sua aplicação, o critério do default iminente é observado com fidelidade pelo Clube de Paris, o que demonstra as funçôes desse grupo de credores: a de um conjunto informado de negociadores interessados no cumprimento das obrigações, e não um centro de oferecimento de concessões generosas de alívio financeiro. Pela restrição do alívio da dívida à hipótese excepcional do risco de inexecução dos pagamentos, apenas contornável pelas concessões dos credores, estes afirmam que não

334 FELDMAN, H. Internationale Umschuldungen im 19. Und 20. Jahrhundert: eine Analyse ihrer Ursachen, Techniken und Grundprinzipien. Berlim: Duncker \& Humblot, 1991, p. 715.

335 RIEFFEL, A. The Role of the Paris Club in Managing Debt Problems. Essays in International Finance, Princeton, n. 161, dez. 1985, p. 5.

336 GRARD, L. Le Club de Paris et les Dettes Publiques des Etats. In: CARREAU, D.; SHAW, M. (Coord.). La Dette Extérieure. Haia: Martinus Nijhoff Publishers, 1995, p. 208. 
se constituem em um grupo de doadores desinteressados. Em apenas um caso o Clube de Paris aceitou renegociar a dívida fora da circunstância de iminente suspensão dos pagamentos: em 1981, o Paquistão se beneficiou da clemência de parcela de seu endividamento em razão da particular situação política regional após a invasão soviética do Afeganistão. Neste caso, credores ocidentais procuraram medidas que contribuíssem para o crescimento econômico paquistanês. Afora esta exceção, porém, o requisito do iminente default tem objeto de constantes reiteraçôes. ${ }^{337}$

Da mesma forma o princípio da condicionalidade, que significa o compromisso do país devedor com a execução de um programa de ajustes estabilizadores sob os auspícios do FMI. Estas medidas representam tanto uma orientação seguida para a inauguração de renegociações no Clube de Paris como um requisito para a validade dos acordos concluídos, que ficam condicionados ao prosseguimento da execução do programa de estabilização. Sua função é assegurar que o devedor readquira condições de cumprir com os encargos da dívida nos termos e nos prazos estabelecidos. A partir de meados dos anos de 1980 estes programas seriam aglutinados sob um conjunto de práticas que passariam a representar, em parte do imaginário político, o epítome de um sistema de crenças e técnicas de imposição dos interesses do mundo desenvolvido sobre os países do sul. Aquele "Consenso de Washington" não deixava, porém, de oferecer uma resposta a uma deficiência dos acordos de reestruturação da dívida bilateral que marcaram determinado período em que se considerava que as causas das crises de endividamento eram exclusivamente exógenas aos países afetados e, portanto, fora de seu controle. A execução de um programa de alívio da dívida, a partir da perspectiva de que as causas dos problemas econômicos eram externas, seria suficiente para resolver os problemas dos níveis elevados de endividamento, uma vez que interrompesse os seus efeitos. Os procedimentos do Clube de Paris a partir de 1984, no entanto, passaram a funcionar pela perspectiva oposta: a de que mesmo os benefícios mais generosos não seriam suficientes para evitar um possível default e a deterioração de seu crédito. Daí que se tornasse mais frequente a adesão a políticas de ajuste concatenadas com a ação do FMI, que associam o crédito concedido pelo Clube a um acordo do tipo stand-by na instituição multilateral, pelo que as novações mais vantajosas ficam pendentes da efetiva implantação de programas que, depois de 1987, passaram a ser conduzidas com base no já mencionado Serviço Aperfeiçoado de Ajuste Estrutural.

337 RIEFFEL, A. The Role of the Paris Club in Managing Debt Problems. Essays in International Finance, Princeton, n. 161, dez. 1985, p. 5. 
Rieffel aponta, no entanto, que a ação do Clube de Paris enfrenta uma contradição até aqui não completamente resolvida: se os ajustes são requisitos para assegurar o serviço da dívida, sua execução deveria tornar o alívio concedido pelo Clube desnecessário; por outro lado, se os credores ali reunidos consentem com a reestruturação sob o argumento de que o default é iminente, se reconhecem as condições de estabilização à qual o devedor teve que aderir foram insuficientes para atingir o seu objetivo. ${ }^{338} \mathrm{O}$ princípio da condicionalidade coloca-se, assim, em alguma contradição com o princípio do default iminente. Esta objeção não impede, porém, que as condicionalidades constituam um dos eixos centrais das renegociações, que se beneficiam da articulação entre o Clube de Paris e o FMI por duas razões básicas. A primeira delas é que o Clube, não dispondo de uma estrutura fixa, se beneficia da participação da equipe técnica e da estrutura do FMI, sem a qual teria pouca capacidade de formulação, execução e monitoramento. Por outro lado, a legitimidade destes programas busca ser fortalecida pela sua veiculação por uma instância que congrega todas as partes, tanto devedoras quanto credoras. ${ }^{339}$

Algumas questôes quanto à eficácia das condicionalidades não se deixam responder completamente por este arranjo, o qual depende, ainda, de que a contrapartida do esforço do devedor - o benefício concedido pelos credores - encontre algum critério de distribuição dos montantes cancelados entre eles, o que vem a ser atendido pelo terceiro princípio. O critério da repartição dos encargos atende, assim, ao que o Clube de Paris denomina de comparabilidade de tratamento entre os credores, que significa a proibição de que o país devedor conceda a algum credor tratamento mais favorável do que aquele consensualmente estabelecido no acordo final. ${ }^{340} \mathrm{~A}$ ideia central é a de que a concessão de alívio envolve custos que não devem recair em maior proporção sobre uma classe de credores em vantagem de outras, o que significa dizer que nenhuma categoria deve estar isenta de arcar com os custos da reestruturação. Trata-se, no entanto, de um princípio de aplicação complexa, descrito pelo FMI mais como uma arte do que como uma ciência. ${ }^{341} \mathrm{Com}$ ele se pretende evitar que o país devedor se empenhe em negociar com cada um

338 RIEFFEL, A. The Role of the Paris Club in Managing Debt Problems. Essays in International Finance, Princeton, n. 161, dez. 1985, p. 7-8.

339 FISCHER, S. The Paris Club at Fifty. BIS Review, Basileia, vol. 57, 2006, p. 1-3.

340 "The Paris Club preserves the comparability of treatment between different creditors, as the debtor country cannot grant to another creditor a treatment less favorable for the debtor than the consensus reached in the Paris Club" (RIEFFEL, L. Restructuring Sovereign Debt: the Case for Ad Hoc Machinery. Washington, D.C.: Brookings Institution Press, 2003, p. 72).

341 Apud RIEFFEL, L. Restructuring Sovereign Debt: the Case for Ad Hoc Machinery. Washington, D.C.: Brookings Institution Press, 2003. 
dos credores condições tão favoráveis quanto possíveis, eventualmente usando para isso reservas que poderiam ser empregadas de forma mais equitativa em negociações multilaterais. Em termos práticos, o princípio do tratamento comparável significa que o acordo concluído com o Clube de Paris servirá de referência para a reestruturação da dívida bancária no seio do Clube de Londres. É assim que este princípio ganha grande significado na etapa posterior das renegociações, que trata das modificações com os credores privados. Há maiores chances de sucesso nas renegociações se estes credores sabem que compartilham perdas de forma semelhante com outros grupos de credores, mais especificamente os oficiais reunidos no Clube de Paris, e que os descontos que deverão oferecer não serão o resultado de uma sobrecarga incompatível com eventual tratamento mais favorável oferecido a outras classes. A mesma lógica se aplica à renegociação com credores oficiais não participantes do Clube de Paris. ${ }^{342}$

Estes princípios, em conjunto com as etapas do processo de renegociação que iniciam com a obtenção de informaçoes, apontam a um grau importante de institucionalização dos procedimentos do Clube de Paris. Os conflitos são repetidamente resolvidos de acordo com critérios que parecem já ter se estabilizado em seu modo de agir. $\mathrm{O}$ acordo conclusivo da renegociação, que contém cláusulas definidoras da reestruturação pactuada, não é, porém, um acordo internacional juridicamente vinculante aos participantes. Os termos em que as obrigações financeiras serão convertidas são assinados ad referendum pelos representantes dos credores e devedores participantes, que se comprometem em recomendá-los aos respectivos governos. Este acordo constitui, portanto, uma minuta, referido como agreed minute, que se caracteriza por ser um ato concertado não convencional, pois os membros do Clube de Paris não representam juridicamente seus respectivos Estados e não têm, portanto, poder decisório. ${ }^{343}$ Apesar de a renegociação transcorrer em um foro multilateral, a eficácia jurídica do acordo depende da conclusão de ulteriores tratados bilaterais entre Estados credores e devedores. O interesse jurídico da minuta consolidada no Clube de Paris, ato derradeiro dos processos ali transcorridos, está na constituição de uma base aceita pelos participantes de reescalonamento ou redução da dívida do país afetado. Com relação aos efeitos jurídicos vinculantes às partes, portanto, sua função é pré-normativa.

342 FELDMAN, H. Internationale Umschuldungen im 19. Und 20. Jahrhundert: eine Analyse ihrer Ursachen, Techniken und Grundprinzipien. Berlim: Duncker \& Humblot, 1991, p. 716.

343 GRARD, L. Le Club de Paris et les Dettes Publiques des Etats. In: CARREAU, D.; SHAW, M. (Coord.). La Dette Extérieure. Haia: Martinus Nijhoff Publishers, 1995, p. 224. 


\subsection{A REESTRUTURAÇÃO DA DÍVIDA BANCÁRIA: O CLUBE DE LONDRES}

Os limites pragmáticos à capacidade de pagamento do Estado são ainda enfrentados em outros foros internacionais reunidos para a renegociação da dívida bancária comercial do Estado, isto é, dos contratos de empréstimos públicos em que os credores são instituições financeiras privadas. A importância crescente desses empréstimos nos financiamentos internacionais é indicada pelo maior envolvimento de instituições bancárias em processos de reestruturação a partir da década de 1970, os quais, nos dois decênios anteriores, ocorreram apenas excepcionalmente em relação à dívida sindicada, de menor relevância. ${ }^{344} \mathrm{~A}$ maior importância da dívida mobiliária como fonte do crédito privado para o Estado tem reduzido a participação dos empréstimos concedidos por consórcios bancários, os quais, no entanto, não são um tema datado da década de 1980 , com alguns casos posteriores. ${ }^{345}$

Durante a renegociação desta parte da dívida pública, os objetivos do Estado devedor e credor devem ser observados em suas particularidades. Obtido um acordo com o FMI e perante os credores do Clube do Paris, resta ainda ao país que busca reestruturar a sua dívida obter uma redução dos encargos com perspectivas de recuperação de crescimento e manutenção da estabilidade econômica. Os objetivos do devedor levam em conta a necessidade de preservar o acesso às fontes de financiamento, organizar os termos da reestruturação de forma a não comprometer o crescimento econômico, estabelecer pagamentos viáveis aos credores, manter um nível adequado de reservas e ser politicamente atingível. Os objetivos dos credores bancários, por sua vez, são menos variados, e dizem respeito a preservar sua credibilidade financeira e sua proporção de ativos e evitar que os empréstimos não reembolsados se transformem em passivos nos seus balanços. A partir destes objetivos, as regras próprias de regulação de bancária de cada país, e ainda regulações internacionais, podem incentivar este ou aquele comportamento. O descumprimento de cronogramas de pagamento de empréstimos faria com que os bancos comerciais americanos, em primeiro lugar, reduzissem o valor contábil dos empréstimos em função da desvalorização de seu valor de mercado, e, depois, os registrassem como um passivo, razão pela qual se dá certa preferência estratégica a conceder

344 FRIEDMAN, I. The Emerging Role of Private Banks in the Developing World. Nova Iorque: Citicorp, 1977, p. 36.

345 Como mostram as reestruturações da dívida bancária do Paquistão, em 1999, de Sérvia e Montenegro, em 2004, da República Dominicana, em 2005, e do Iraque, em 2006 (cf. DAS, U.; PAPAIOANNOU, M.; TREBESCH, C. Sovereign Debt Restructurings 1950-2010: Literature Survey, Data, and Stylized Facts. Washington, D.C.: FMI, 2012, p. 19). 
novos financiamentos para manter os empréstimos na lista dos ativos. Os bancos europeus, a seu turno, submetidos a regras contábeis distintas, tendem a evitar refinanciamentos e preferem capitalizar os juros de mora. Diante do não reembolso dos empréstimos públicos, observa-se também uma diferença quanto a bancos pequenos e grandes. Os primeiros, menos expostos a riscos sistêmicos, manifestam menor preferência pela concessão de novos empréstimos para refinanciar o devedor, com maior tendência a aceitar propostas de reestruturação. Os segundos, por sua vez, têm, em razão da significativa exposição, maiores incentivos para prover com novos créditos o devedor cujas obrigações financeiras se encontrem em risco. ${ }^{346}$ A partir destas características é que se busca um acordo entre o Estado devedor e os consórcios bancários credores.

$\mathrm{Na}$ etapa posterior à suspensão consensual ou unilateral dos pagamentos, é relevante que se organizem as renegociações de forma a estimular o comportamento cooperativo dos participantes, que tende a reduzir o antagonismo e a resistência às propostas de reestruturação formuladas. Uma solução corrente em relação à dívida com instituições financeiras privada é a formação de comitês de credores, dos quais há exemplos relevantes. $\mathrm{O}$ mais célebre deles foi a Corporation of Foreign Bondholders, fundado pela Grã-Bretanha em 1868 e extinto apenas em 1988, mas também se poderia citar a experiência da Association Nationale des Porteurs Français de Valeurs Mobilières, criada pelo governo francês em 1898. Estas experiências, no entanto, envolviam o agrupamento e a participação de portadores de títulos públicos de uma nacionalidade específica, cujos interesses eram representados no comitê. Nada significativamente parecido com o que se passaria a partir da década de 1970, em que estavam em questão empréstimos contratuais bancários. Se, atualmente, as negociações se desenvolvem no Bank Advisory Committee (BAC), também conhecido como Clube de Londres, este grupo é fruto de uma experiência recente. Suas origens são incertas e, apesar da denominação poder conduzir a equívocos de localização geográfica, pois suas reuniōes ocorreram, na maior parte das vezes, em Nova Iorque, ${ }^{347}$ desenvolveram-se no Clube de Londres procedimentos reconhecíveis de reestruturação da dívida perante consórcios bancários, os quais são o produto de uma experiência menos imediata que a do Clube de Paris. A denominação se deve ao fato de que os reescalonamentos da dívida sindicada normalmente

346 MEGLIANI, M. Sovereign Debt: Genesis, Restructuring, Litigation. Heidelberg: Springer, 2015, p. 325-326.

347 RIEFFEL, L. Restructuring Sovereign Debt: the Case for Ad Hoc Machinery. Washington, D.C.: Brookings Institution Press, 2003, p. 108. 
optam pela aplicação da lei inglesa e porque a previsão das taxas de juros variáveis é estabelecida em função da taxa LIBOR (London Interbank Offered Rate). ${ }^{348}$ Vista em perspectiva, a atuação do clube bancário em seu momento de maior atividade nos anos de 1980, são o resultado de um processo anterior desencadeado pelas dificuldades de servir à dívida enfrentadas, na década anterior, por Zaire, Peru, Turquia, Sudão e Polônia. ${ }^{349}$

Como se nota, a estrutura dos fluxos de capitais havia se transformado de maneira importante, com um número agora reduzido de agentes participantes. Se, durante os anos anteriores à segunda guerra, os empréstimos internacionais se davam corriqueiramente pela forma de títulos, em se tratando de credores privados, e de operações de país a país, quando o credor fosse outro ente soberano, este padrão foi alterado com o rápido crescimento de operações de crédito de longo prazo perante bancos comerciais. Rieffel argumenta detalhadamente em favor de uma relação sequenciada entre o desenvolvimento significativo de um mercado mais receptivo a empréstimos realizados por consórcios bancários e destinados a países em desenvolvimento, as posteriores dificuldades de pagamentos destas obrigações e, finalmente, a busca de uma arquitetura institucional para a construção de mecanismos de resolução eficiente. O Clube de Londres como local destas renegociações não foi fruto, porém, de iniciativas do setor público ou do setor bancário como um todo, mas de um punhado de negociações iniciadas ad hoc por algumas instituições financeiras diante de devedores que possivelmente deixariam de executar os pagamentos das obrigações contratadas, se ainda não o tivessem feito. Estes casos, somados aos procedimentos já estabelecidos pelo Clube de Paris e à experiência dos grupos de negociação de títulos públicos anteriores à segunda guerra, contribuíram todos para a consolidação dos procedimentos do Clube de Londres. ${ }^{350}$

Em contraste com comitês de credores anteriores, o BAC apresenta vocação global por não representar credores de apenas uma nacionalidade, mas um conjunto de bancos comerciais internacionais. A estrutura organizacional é, no entanto, precária, porque carente de um estatuto, de um secretariado ou mesmo de instalações

348 WOOD, P. Principles of International Insolvency. 2. ed. Londres: Sweet \& Maxwell, 2007, vol. 1, p. 785.

349 STURZENEGGER, F.; ZETTELMEYER, J. Debt Defaults and Lessons from a Decade of Crises. Cambridge: the MIT Press, 2006, p. 12.

350 "In short, several years of experimentation were required to design the London Club process. It grew out of centuries of commercial bank experience with delinquent borrowers of all kinds" (RIEFFEL, L. Restructuring Sovereign Debt: the Case for Ad Hoc Machinery. Washington, D.C.: Brookings Institution Press, 2003, p. 1268). 
físicas. Mesmo os serviços de informações sobre a situação dos devedores afetados são prestados por um ente auxiliar, o Institute of International Finance. ${ }^{351}$ As reunióes do comitê são organizadas caso a caso e presididas por um representante do banco mais exposto ao risco do crédito ali considerado. É possível indagar qual é a razão para que um grupo de credores formalmente desorganizado tenha tamanha influência sobre os devedores, tanto mais que, assim como as negociações passadas no Clube de Paris, o resultado do processo é uma proposta de acordo sem força vinculante. $\mathrm{O}$ poder dos credores bancários está, porém, no impacto das sançôes econômicas de um eventual descumprimento, com o bloqueio de novos empréstimos. Sob este aspecto, o Clube de Londres tende a ser uma instância de solução de controvérsias bastante eficiente. ${ }^{352}$

Não há uma definição precisa dos princípios que regem a ação do Clube de Londres, o que deixa margem para o questionamento da uniformidade dos procedimentos seguidos. Rieffel apresenta, no entanto, algumas orientaçôes comuns seguidas nas cerca de duzentas reestruturações até aqui concluídas com credores bancários nesta sede. O primeiro destes princípios é a reestruturação ad hoc, segundo o qual os acordos de resolução são fixados segundo as circunstâncias de caso a caso. Trata-se do reconhecimento de que as particularidades financeiras de cada devedor e a peculiar composição de sua dívida pública devem determinar soluçôes compatíveis com suas especificidades. ${ }^{353}$ Este método de solução ad hoc, recitado nas inúmeras renegociações do Clube de Londres, não é incompatível com outras soluções institucionais que apontam para a necessidade de maior previsibilidade das regras aplicáveis aos mecanismos de resolução da inexecução da dívida pública porque a existência de um quadro normativo mais explícito convive bem com a previsão de que os acordos serão concluídos de acordo com o caso concreto. Não há, assim, incompatibilidade entre um princípio de reestruturação ad hoc e arranjos institucionais que disciplinem formas de condução das renegociaçôes.

351 PARKINSON, F. Some Legal and Institutional Aspects of the Debt Crisis. In: BUTLER, W. International Law and the International System. Dordrecht: Martinus Nijhoff, 1987, p. 157.

352 STURZENEGGER, F.; ZETTELMEYER, J. Debt Defaults and Lessons from a Decade of Crises. Cambridge: the MIT Press, 2006, p. 13.

353 RIEFFEL, L. Restructuring Sovereign Debt: the Case for Ad Hoc Machinery. Washington, D.C.: Brookings Institution Press, 2003, p. 1339. Este princípio também se encontra mencionado em outros trabalhos. Cf., por exemplo, a referência de H. Feldmann à fallweise Umschuldung aplicável à reestruturação da dívida bilateral e sindicada (Internationale Umschuldungen im 19. Und 20. Jahrhundert: eine Analyse ihrer Ursachen, Techniken und Grundprinzipien. Berlim: Duncker \& Humblot, 1991, p. 716). 
A voluntariedade é outro mencionado vetor de atuação, consubstanciado na própria existência de renegociações. Estas significam, como exposto no início deste capítulo, que bancos credores e o país devedor encetam procedimentos negociados para produzir o acordo de reestruturação. Uma primeira implicação deste princípio é que conversões forçadas da dívida pública, que já ficavam vedadas no Clube de Paris, seguem como práticas negadas pelo Clube de Londres, o que permite afirmá-la como um parâmetro de ação dos clubes de reestruturação da dívida pública. A consequência de modificaçõos unilaterais dos contratos é o cancelamento dos procedimentos de renegociação. Não é apenas à condenação da hipótese extrema de uma conversão forçada que se dirige o princípio da voluntariedade, entretanto. Em sentido mais amplo, o acordo produzido deve ter sido mutuamente discutido pelas partes, e se apresenta como resultado de negociações substanciais. Desta forma, o oferecimento pelo país devedor de exit offers, por meio da qual é apresentada uma oferta de reestruturação que permite ao credor apenas as opções de adesão ou retirada, tampouco se coaduna com o sentido dos procedimentos do Clube de Londres, que requerem a formação de consensos substantivos e a definição do conteúdo das modificações entre todos os credores. ${ }^{354}$

Por fim, uma das orientações mais importantes do Bank Advisory Committee é que as reestruturações atendam a princípios de mercado, o que significa que as renegociações não se destinam precipuamente a oferecer concessões aos países que a iniciam, mas a recuperar, de forma flexível, pragmática e, tanto quanto possível, despolitizado fluxo do serviço da dívida. ${ }^{355}$ Este princípio implica a condução de renegociações em termos exclusivamente comerciais, afastadas que estão do oferecimento de apoio financeiro aos devedores para atingir a propósitos políticos. Cancelamentos da dívida não constituem parte precípua, portanto, do aparato instrumental do Clube de Londres, a não ser em raríssimas exceções, nas quais se levou em conta o resultado obtido no Clube de Paris e a exigência de tratamento comparável entre todas as classes de credores. Assim, as reduções oferecidas pelos credores oficiais à Polônia, em 1991, em razão de sua colaboração com a queda dos regimes comunistas no Leste europeu, e ao Egito, por sua participação nos acordos de paz de Camp David, em 1978, implicaram também reduções previstas nos acordos

354 Ver, neste trabalho, o item 2.3.1.1. Como referência bibliográfica, cf. WAIBEL, M. Sovereign Defaults before International Courts and Tribunals. Cambridge: Cambridge University Press, 2011, p. 14. As exit offers também podem ser referidas como um resultado cram down.

355 RIEFFEL, L. Restructuring Sovereign Debt: the Case for Ad Hoc Machinery. Washington, D.C.: Brookings Institution Press, 2003, p. 1350 e seguintes. 
obtidos no Clube de Londres, sob o risco de que, caso os termos comparáveis não fossem obtidos, se invalidassem os acordos anteriores. ${ }^{356}$

Sob o aspecto técnico, dois mecanismos são empregados para assegurar que as reestruturaçōes transcorram de forma não concessional: a fixação da taxa de juros da dívida reestruturada acima da taxa LIBOR, pois qualquer previsão abaixo sinalizaria índices inconsistentes com as práticas comerciais, e, nos casos em que a incapacidade de pagamento do devedor requeira reduções, que estas sejam compatíveis com a percepção de mercado sobre o risco do crédito associado aos novos empréstimos. Como argumentam as instituições financeiras participantes, elas possuem deveres perante seus acionistas que fariam com que a concessão de descontos para além do risco objetivamente avaliado evidenciasse, nas negociaçóes, um "elemento de caridade" que é incompatível com estas responsabilidades. 357

Em comparação com as técnicas de reestruturação da dívida pública, que são significativamente distintas ao longo do tempo, os princípios básicos apresentados apresentam-se de forma constante nas renegociaçôes internacionais da dívida pública, aqui apresentadas em seus dois foros mais emblemáticos, o Clube de Paris e de Londres, e em suas relações com o Fundo Monetário Internacional. Sob este aspecto se delineia uma institucionalização de procedimentos de reestruturação da dívida pública multilateral, bilateral e sindicada. A despeito dos diferentes aspectos técnicos dos acordos concluídos, há um modo de agir identificado com o que aqui se chamou de princípios orientadores das renegociaçōes. A existência de contornos básicos, porém, não indica a plena eficácia dos resultados obtidos, pois as crises da dívida pública continuaram a se apresentar com frequência e a conclusão de acordos de reestruturação não foi suficiente para evitar reestruturações posteriores. $\mathrm{O}$ debate sobre a "arquitetura financeira internacional" da dívida pública é, diante de cenários financeiros continuamente desafiadores, ainda presente.

O tema que se coloca ao debate jurídico internacional da dívida pública é, portanto, o de mecanismos de resolução da dívida pública diante de cenários ainda não organizados de reestruturação, o que se mostra mais presente no tocante à dívida mobiliária tomada perante credores atomizados e desorganizados, haja vista

356 Para o caso polonês, ver SPERLING, J.; KIRCHNER, E. Recasting the European Order: Security Architectures and Economic Cooperation. Manchester: Manchester University Press, 1997, p. 178 e seguintes. Para o caso egípcio, ver WEISS, D.; WURZEL, U. The Economics and Politics of Transition to an Open Market Economy: Egypt. Paris: Development Centre of the OECD, 1998, p. 41 e seguintes.

357 Como a ele se refere RIEFFEL, L. Restructuring Sovereign Debt: the Case for Ad Hoc Machinery. Washington, D.C.: Brookings Institution Press, 2003, p. 1384. 
algum grau de estruturação dos procedimentos de resolução da inexecução perante credores contratuais, identificáveis e organizados em foros multilaterais ou consórcios bancários. Os aspectos dos arranjos estruturais que se apresentam para aperfeiçoar as atuais dinâmicas da renegociação da dívida pública se desdobram, normalmente, na proposta de criação de novas instituições ou no preenchimento de lacunas contratuais presentes no financiamento do Estado pela emissão de títulos públicos. A dívida mobiliária ampla contribui para que se acumulem complexidades diante de crises. Há um caso que apresenta elevada potencialidade analítica a respeito das características mais marcantes sobre desafios atualmente presentes nas reestruturaçõos, e este é o caso argentino. O exemplo servirá para mostrar como, a partir de causas econômicas particulares, o cenário relativamente organizado dos três círculos de renegociações expostos neste capítulo se mostra, concretamente, bastante fragmentado diante da atuação fracionária de outras instâncias de solução de conflitos. A partir do recente pleito da Organização das Nações Unidas por uma moldura multilateral da reestruturação da dívida pública em âmbito internacional, que se associa à busca de uma resposta a parte dos problemas econômicos enfrentados pela Argentina, pode-se oferecer um quadro mais claro das debilidades dos atuais mecanismos jurídicos de enfrentamento das crises da dívida pública em âmbito internacional. 